\title{
La escritura del shock: crisis y poesía en España
}

\section{Incluye anexo con entrevistas a jóvenes poetas}

The shock writing: crisis and poetry in Spain

\section{Ángela Martínez Fernández \\ UNIVERSITAT DE VALÈNCIA·anmarfe3@alumni.uv.es}

Graduada en Estudios Hispánicos por la Universitat de València, donde fue becaria de colaboración en el Departamento de Filología Española. Sus principales líneas de investigación giran en torno al descubrimiento de la producción poética y marginal de autores jóvenes y las representaciones culturales en la crisis española. En la actualidad se encuentra investigando sobre este último aspecto mientras cursa el Máster en Estudios Hispánicos Avanzados de la UV.

RECIBIDO: 5 DE SEPTIEMBRE DE 2014

ACEPTADO: 15 DE NOVIEMBRE DE 2014

Resumen: El presente trabajo consiste en el análisis de la emergencia de nuevas subjetividades provocadas por el estado de shock neoliberal que ha tenido lugar en España y su cristalización en la escritura a través de tres poemarios de autores jóvenes. Partimos en primer lugar de la redefinición del concepto de shock, describiendo por un lado el shock político y, por otro, el shock estético; a continuación se lleva a cabo una explicación del panorama poético actual que engloba a los poetas jóvenes aquí estudiados y las tendencias que comienzan a seguir $y$, finalmente, se lleva a cabo un análisis detallado de los tres libros para constatar dicha emergencia de nuevas subjetividades provocadas por la dinámica neoliberal en el plano poético español.

Palabras Clave: shock, neoliberalismo, capital, subjetividades, crisis, franquismo, transición, reforma psiquiátrica, cine documental.

\begin{abstract}
The article focus in the relationship between the emergency of new subjectivities shocked by the Spanish neoliberalism and the creation of new poetical voices in some books written by young poets. The article starts exploring the two main dimensions of the 'shock' concept: in the political way and in the aesthetic one. Then, the article focus in the way some young Spanish poets use the aesthetic shock as a way for struggling the political shock of neoliberalism.
\end{abstract}

Key Words: Shock, Neoliberalism, Subjectivity, Poetry, Spanish Crisis. 


\begin{abstract}
"En esos períodos maleables, cuando no tenemos un norte psicológico y estamos físicamente exiliados de nuestros hogares, los artistas de lo real sumergen sus manos en la materia dócil y dan principio a su labor de remodelación del

mundo."

NAOMI KLEIN

"La poesía no puede derribar a una dictadura, pero sin poesía no hay absolutamente ninguna posibilidad de derribarla."
\end{abstract}

RAÚl ZURITA

\title{
0. Introducción
}

El objetivo principal de este trabajo es reflexionar sobre la relación posible entre la emergencia de nuevos lenguajes poéticos y el turbulento contexto socio-económico que atraviesa la sociedad española en los últimos años. Para ello, se llevará a cabo un análisis de dos libros colectivos y un libro anónimo de consulta exclusivamente virtual, publicados en los últimos años por poetas jóvenes residentes en España (Tenían veinte años y estaban locos, 2011; La calle de las impertinencias, 2012; El bate de béisbol de Michael Douglas, 2014), poniendo en relación sus poéticas con algunos de los procesos y dinámicas sociales en los que sus autores se han visto inmersos, así como la mayoría de la sociedad española. Se tratará de analizar, por tanto, la relación entre las voces que construyen los poemas, los sujetos que hablan en ellos y las dinámicas sociales en las que esas voces y sujetos toman cuerpo. Un concepto central, que ha sido utilizado tanto en la tradición estética como en la filosofía política y en la historia económica, servirá para establecer, desde el primer momento, esa relación: el concepto de shock.

La estructura que se seguirá para explicar esta relación entre poesía y crisis en España será la siguiente: en primer lugar, una indagación teórica por el concepto de shock tanto en su vertiente política como en su vertiente estética, en segundo lugar un recorrido contextualizador del panorama poético actual y en tercer lugar un análisis concreto de los dos libros colectivos y el poemario anónimo. Todo ello estará orientado a responder una serie de preguntas centrales: ¿qué tipo de nuevas subjetividades han nacido en el estado de shock provocado por la dinámica neoliberal? ¿Qué nueva tendencia de conducta poética puede verse en los libros de los autores jóvenes españoles? ¿De qué manera ese choque del que son víctimas traspasa la escritura e interpela a los lectores? 


\section{Poéticas del shock}

\subsection{El neoliberalismo y sus efectos en la subjetividad}

La producción poética de los autores jóvenes que se estudia en el presente trabajo se enmarca en una realidad socio-histórica o racionalidad social determinada: el neoliberalismo y una de sus consecuencias directas: los estados de shock en el sentido que Naomi Klein da a ese término. Siguiendo la última obra de Laval y Dardot, el neoliberalismo es la racionalidad actual imperante y, por ello, se repite ya en la primera página la sentencia que abría la edición del año 2009: "No hemos terminado con el neoliberalismo". Esto supone, por tanto, que a pesar de las repetidas crisis mundiales y los planes de austeridad implantados por los diferentes Estados, no se ha desembocado en un debilitamiento sino en un refuerzo brutal de las políticas neoliberales. "En tanto racionalidad, supone una estructuración y organización no solo de la acción de los gobernantes, sino también de la conducta de los propios gobernados" (2013: 15).

El neoliberalismo define cierta norma de vida en las sociedades occidentales y, más allá de ellas, en todas las sociedades que las siguen en el camino de la modernidad. Esta norma obliga a cada uno a vivir en un universo de competición generalizada, impone tanto a los asalariados como a las poblaciones que entren en una lucha económica unos con otros, sujeta las relaciones sociales al modelo del mercado, empuja a justificar desigualdades cada vez mayores, transforma también al individuo, que en adelante es llamado a concebirse y conducirse como una empresa (2013: 14).

Competencia, lucha económica, modelo de empresa y de mercado. Estos conceptos cristalizan la esencia del neoliberalismo y especifican el nuevo tipo de subjetividad que nace en torno a ella y que conlleva, por tanto, la aparición de un nuevo tipo de sujeto que se concibe a sí mismo como una empresa. "La racionalidad neoliberal tiene como característica principal la generalización de la competencia como norma de conducta y de la empresa como modelo de subjetivización" (2013: 15). El sujeto neoliberal, por tanto, es el hombre competitivo, introducido dentro de la lógica de la empresa como modelo subjetivo de vida, lo que supone que su objetivo principal gire en torno a la utilidad en tanto ciudadano-empresa. No obstante, hay un factor importante en todo este proceso y es que el hombre neoliberal debe sostener su competitividad en torno a aquel agente que regula la empresa y el mercado: el capital. "El neoliberalismo es la razón del capitalismo contemporáneo, un capitalismo sin el lastre de sus referencias arcaizantes y plenamente asumido como construcción histórica y norma general de la vida" (2013: 15). Ahora bien, ¿qué efectos produce ese modelo en la subjetividad? ¿Cómo se consigue que el ciudadano adopte un modelo de conducta basado en la competitividad que impone el capitalismo? El proceso es extremadamente complejo y fue tratado por M. Foucault a partir de lo que él denominó la racionalidad gubernamental (una forma de entender el gobierno como actividad más que como institución) ${ }^{1}$.

${ }^{1}$ El término gubernamentalidad fue introducido, precisamente, para significar las múltiples formas de esa actividad mediante la cual los hombres, que pueden pertenecer o no a un gobierno, 
De acuerdo a los trabajos de Foucault, por tanto, el surgimiento de esta nueva subjetividad neoliberal ha sido posible gracias a una racionalidad gubernamental que no se limita al control económico y político, sino que, sobre todo, introduce el poder y el control en la vida privada del individuo y en su propio cuerpo. El modelo teórico del panóptico es, en la teoría foucaultiana, un emblema de esta forma de moldeado subjetivo desde el siglo XVIII: un modo de legislación indirecta mediante la cual el individuo interioriza la vigilancia que, en un primer momento, era tan solo externa ${ }^{2}$. De ese modo, el gobierno en la modernidad no solo legisla y marca lo que se puede y no se puede hacer, sino que "penetra hasta el pensamiento del individuo, lo acompaña, lo orienta, lo estimula, lo educa" (Laval, 2013: 329). Habla también Foucault no solo de este método indirecto, sino también de un dispositivo de eficacia que garantiza la normalización de las técnicas disciplinarias. "Fue preciso pensar e instalar, mediante una estrategia sin estrategas, los tipos de educación del espíritu, de control del cuerpo, de organización del trabajo, de reposo y de ocio, que eran la forma institucional del nuevo ideal del hombre, al mismo tiempo individuo calculador y trabajador productivo" (Laval, 2013: 329). Puede concluirse, por tanto, que todo ello es un proceso con etapas conectadas que desembocan en la realidad actual: la racionalidad gubernamental, apoyada en dispositivos de eficacia, implanta la lógica neoliberal basada en el funcionamiento de la empresa capitalista.

La idea fundamental que subyace en la racionalidad social actual en la que se desenvuelven los poetas estudiados es que el neoliberalismo implica una completa reordenación de la lógica social, de la economía y de las instituciones (privatización general, desaparición de servicios públicos, competitividad), pero al mismo tiempo implica la emergencia de nuevas subjetividades. Por una parte, hay sujetos que se adaptan a las exigencias del sistema y a su normatividad social y por otra parte hay sujetos que no se adaptan y que viven de forma traumática la revolución ${ }^{3}$ neoliberal. En ese sentido, podemos hablar de subjetividades normativas (el sujeto neoliberal del que hablan Laval y Dardot) y subjetividades díscolas, que viven de forma conflictiva o traumática los procesos de neoliberalización.

Esta doble vertiente del neoliberalismo tiene consecuencias también en las formas de resistencia. Si la biopolítica ${ }^{4}$ neoliberal afecta a todos los órdenes de la vida, la resistencia al

pretenden conducir la conducta de otros hombres, o sea, gobernarlos [...] gobernar no es gobernar contra la libertad o a pesar de ella, es gobernar mediante la libertad, o sea, jugar activamente con el espacio de libertad dejado a los individuos para que acaben sometiéndose por sí mismos a ciertas normas (Laval y Dardot, 2013: 16).

${ }^{2}$ En su obra Vigilar y castigar. Nacimiento de la prisión, publicada en 1975, Michel Foucault realiza un recorrido a través de cuatro partes interconectadas (Suplicio, Castigo, Disciplina, Prisión) donde analiza los mecanismos llevados a cabo en los sistemas penales de Occidente durante la era moderna que derivaron en la interiorización del panóptico y el surgimiento de las sociedades disciplinarias.

${ }^{3}$ Se habla de revolución porque implica un cambio radical de la estructura social a través de una buena dosis de violencia. Tomás Moulian, David Harvey o Naomi Klein han conceptualizado este proceso.

${ }_{4}$ El concepto de biopolítica fue desarrollado por Michel Foucault para aludir a una de las transformaciones esenciales de la política en la modernidad: aquella por la cual el cuerpo humano y sus procesos fisiológicos entraban a formar parte de las preocupaciones centrales del poder. En su 
neoliberalismo no podrá ser solo lucha contra recortes y privatizaciones, sino también lucha en horizonte biopolítico, lucha por las formas de vida, por los modos de subjetivación ${ }^{5}$. El estado neoliberal no solo modifica las estructuras externas del sistema sino también las estructuras internas o subjetivas, de manera que la lucha contra el neoliberalismo también puede llevarse a cabo en el terreno de la subjetividad y de las formas de vida. Y ese es, precisamente, el terreno de juego de la poesía.

\subsection{La doctrina del shock}

Una vez llegados a este punto, es preciso constatar cómo ese funcionamiento neoliberal se sustenta en los denominados estados de shock, tal y como los explica la autora Naomi Klein: "un estado de shock, por definición, es un momento en el que se produce una pausa entre acontecimientos que se están sucediendo a gran velocidad y la información existente acerca de ellos" (Klein, 2007: 595), es decir, un periodo de desconcierto y aislamiento causado por la sucesión de hechos violentos. Con respecto a este concepto podrían distinguirse dos vertientes o dos modos de aplicación: por un lado, el shock individual y, por otro, el shock colectivo. El primero de ellos se constituye como uno de los puntos fundamentales en los procesos interrogatorios (tortura), donde el detenido es aislado tanto física como psicológicamente para causar en él confusión, desorientación y sorpresa, de manera que pueda extraérsele toda la información deseada. El segundo de ellos es tratado por extenso en la obra de Naomi Klein La doctrina del shock. El auge del capitalismo del desastre publicado en 2007, en la que realiza un recorrido por diferentes épocas y lugares donde la política neoliberal ha derivado en estados de shock colectivos.

En la teoría de Klein hay dos puntos clave que derivan y dan lugar al estado de shock colectivo: por un lado, Milton Friedman o el origen intelectual y, por otro lado, el capitalismo del desastre. En todo proceso económico, político o social existe un principio, un origen fundacional (tal y como sucedía con el Panóptico de Foucault que nacía en los sistemas penales y derivaba en las sociedades disciplinarias). En este caso, el nombre del Premio Nobel de Economía Milton Friedman surge como el origen a este estado de shock colectivo:

Durante más de tres décadas, Friedman y sus poderosos seguidores habían perfeccionado precisamente la misma estrategia: esperar a que se produjera una

desarrollo del concepto, la biopolítica alude al modo en que los regímenes de poder intervienen en las formas de vida concretas de los individuos, en sus vivencias del cuerpo y de los afectos. Es por ello que con el nacimiento de la biopolítica en la modernidad crece la importancia de la idea de norma frente a la idea tradicional de ley. Si anteriormente se trataba de aplicar o desaplicar la muerte por la voluntad soberana, el biopoder moderno trata de distribuir lo viviente en un dominio de valor y de utilidad. Escribe Foucault: "Un poder semejante debe calificar, medir, apreciar y jerarquizar, más que manifestarse en un brillo asesino; no tiene que trazar la línea que separa a los súbditos obedientes de los enemigos del soberano; realiza distribuciones en torno a la norma"(1978: 174).

5 "Las luchas actuales [...] destruyen la distinción tradicional entre luchas económicas y luchas políticas. Ahora, las luchas son a la vez económicas, políticas y culturales y por lo tanto son luchas biopolíticas, luchas por la forma de vida. Son luchas constitutivas que crean nuevos espacios públicos y nuevas formas de comunidad"(Negri y Hardt, 2002: 66). 
crisis de primer orden o estado de shock, y luego vender al mejor postor los pedazos de la red estatal a los agentes privados mientras los ciudadanos aún se recuperaban del trauma, para rápidamente lograr que las reformas fueran permanentes (2007: 27).

Friedman, por tanto, es una de las figuras sustentadoras del sistema capitalista contemporáneo. Su modus operandi es el siguiente: una catástrofe no supone un problema, sino un beneficio, ya que ello permite empezar de nuevo y empezar de nuevo solo puede suponer reconducir a la sociedad hacia el sistema privado. Podría decirse que Friedman trabaja con una política del aprovechamiento: cuando estalla la crisis en cualquiera de sus manifestaciones (atentados, tsunamis, guerras, desastres económicos), se aprovecha el derrumbe como un nuevo punto de partida, siempre enfocado y dirigido hacia la ampliación del sistema privado. Él mismo define su política con la siguiente sentencia: "solo una crisis da lugar a un cambio verdadero". Ahora bien, si lo que sucede es que Friedman implanta este modo de proceder en las diferentes sociedades contemporáneas (el desastre es una oportunidad de progreso), ¿cómo lo lleva a cabo y qué genera? ¿qué elementos le permiten implantar esta política del aprovechamiento en las diferentes sociedades de la era contemporánea?

Estos ataques organizados contra las instituciones y bienes públicos, siempre después de acontecimientos de carácter catastrófico, declarándolos al mismo tiempo atractivas oportunidades de mercado, reciben un nombre en el trabajo de Klein: capitalismo del desastre (2007: 26). Este segundo concepto clave se basa en la dinámica siguiente: el sistema neoliberal, basado en la lógica de la empresa y esta, a su vez, en el capitalismo, aprovecha las situaciones de desastre (y por tanto confusión social) para generar nuevas riquezas $^{6}$. Lo que produce la política de Friedman es, precisamente, ese capitalismo del desastre, que está sustentado en catástrofes colectivas. Ahora bien, si lo que genera Friedman y sus seguidores es un capitalismo del desastre, este solo puede sostenerse mediante estados de shock colectivos:

Friedman predijo que la velocidad, la inmediatez y el alcance de los cambios económicos provocarían una serie de reacciones psicológicas en la gente que «facilitarían el proceso de ajuste». Acuñó una fórmula para esta dolorosa táctica: el 'tratamiento de choque' económico. Desde hace varias décadas, siempre que los gobiernos han impuesto programas de libre mercado de amplio alcance han optado por el tratamiento de choque que incluía todas las medidas de golpe, también conocido como 'terapia de $\operatorname{shock}^{\prime}$ (2007: 28).

Los estados de shock colectivos, por tanto, son momentos concretos de trauma en las sociedades causados por algún tipo de desastre (tsunami, atentado, crisis económica), que generan sobre todo miedo y desorden en la población, de manera que esta acepta medidas gubernamentales extremas que no habría aceptado "en la tiranía del statu quo"

${ }^{6}$ Es la denominada violencia sistémica de la que habla Žižek en su obra Sobre la violencia. Seis reflexiones marginales. Afirma Žižek: la violencia sistémica es "la consecuencia a menudo catastrófica del funcionamiento homogéneo de nuestros sistemas económico y político"(2009: 10). 
(2007: 27). La doctrina de shock económica necesita, para aplicarse sin ningún tipo de restricción [...] algún tipo de trauma colectivo adicional, que suspenda temporal o permanentemente las reglas del juego democrático (2007: 33). De manera que los estados de shock colectivos pueden definirse como estados de excepción psicológicos donde la población se encuentra aterrorizada y, por tanto, no es dueña de una posesión plena de sus facultades.

Ahora bien, ¿qué papel juega el gobierno en todo este proceso neoliberal de aprovechamiento? Tal y como afirma Klein, en estas situaciones el gobierno se convierte en el inversor capitalista y, después, en el principal cliente de dicho capitalismo del desastre. La autora habla acerca de una "trinidad política": eliminación del rol público del Estado, absoluta libertad de movimientos de las empresas y gasto social prácticamente nulo (2007: 38). Y atribuye un término para definir la alianza que surge entre el gobierno y el sector empresarial: sistema corporativista. Este sistema, por tanto, se basa en traspasar las riquezas públicas al sistema privado (el objetivo principal de la política de Friedman). No obstante, matiza: "una de las características del Estado corporativista es que suele incluir un sistema de vigilancia agresiva [...] encarcelamientos en masa, reducción de las libertades civiles y a menudo, aunque no siempre, tortura" (2007: 39)7.

En conclusión, todo ello es un proceso donde los elementos están interrelacionados: se produce un estado de shock colectivo y automáticamente la catástrofe genera nuevas riquezas (capitalismo del desastre) en el sector privado que el gobierno genera y consume. Tal y como se afirmaba al principio de esta explicación, existen dos tipos de shock: el individual y el colectivo, de manera que lo que sucede es una extrapolación del mecanismo individual hacia el colectivo:

Así funciona la doctrina del shock: el desastre original - llámese golpe, ataque terrorista, colapso del mercado, guerra, tsunami o huracán - lleva a la población de un país a un estado de shock colectivo [...] Como el aterrorizado preso que confiesa los nombres de sus camaradas y reniega de su fe, las sociedades en estado de shock a menudo renuncian a valores que de otro modo defenderían con entereza. (2007: 41).

\subsection{El shock en España: la crisis}

"España sufre la crisis más desigual. Los ingresos del 10\% de los más pobres caen 7,5 veces más que la renta del $10 \%$ más rico."

(El País, 19/06/2014)

"Hacer plaza es oponer un mundo a otro o poner un mundo en otro. Muy concretamente, en situación, con el cuerpo, agujerear la definición instituida de la realidad y producir nuevos sentidos para la vida social."

(Fernández-Savater, 2014)

7 Esto hace referencia a dos de los conceptos claves en la teoría foucaultiana: sociedades disciplinarias y Panóptico. 
La crisis que afecta a España comenzó en el año 2008 como una crisis puramente económica ligada al sector inmobiliario que había tenido lugar primeramente en las principales entidades financieras estadounidenses y se había expandido por toda Europa, generando la quiebra de otras entidades importantes dedicadas al crédito hipotecario y a la titulización de activos. En España, ya desde abril de 2007, las principales inmobiliarias comenzaron a presentar suspensión de pagos que generaron el estallido de la burbuja inmobiliaria y, junto a ello, la bajada de ingresos económicos a nivel mundial fue agravando la situación. El encarecimiento repentino de la vivienda y las sucesivas quiebras de entidades mundiales fueron derivando en una serie de consecuencias como la crisis bancaria del año 2012 y el elevado aumento del desempleo en España (y en Europa).

El elevado déficit público de administraciones municipales y autonómicas, el incipiente y cada vez más visible problema de la corrupción política (desmantelamiento de cuentas en Suiza por parte de algunos dirigentes en partidos políticos), el incremento elevado de la emigración, la disminución drástica del crédito a pequeños empresarios y familias pertenecientes a la clase media o las privatizaciones en el sector público por parte del gobierno central son algunos de los factores que han ido contribuyendo al agravamiento de la situación española. La crisis, por tanto, no se ha limitado al sector económico, sino que ha expandido su influencia en otros ámbitos como el social y el cultural, generando una Gran Recesión Española (2008-2014).

En el año 2014, José Martínez Rubio destacaba algunas de las consecuencias económicas y sociales basándose en los últimos informes y datos oficiales: deuda española de 954.863 millones de euros, 225.000 emigraciones, 6 millones de desempleados ${ }^{8}$. Siguiendo la obra de Naomi Klein, esta crisis se constituye como uno de los estados de shock generado por un sistema capitalista que pretende la privatización de los servicios públicos. La crisis española, en tanto estado de shock, supone un momento concreto de trauma en la sociedad causado por un desastre inicial (el estallido de la burbuja inmobiliaria) que ha generado miedo y desorden en la población. "La doctrina de shock económica necesita, para aplicarse sin ningún tipo de restricción [...] algún tipo de trauma colectivo adicional, que suspenda temporal o permanentemente las reglas del juego democrático" (Klein, 2007: 33). El estado de shock en España, por tanto, ha generado miedos y desórdenes que han permitido a los dirigentes gubernamentales aplicar medidas de privatización aprovechando esos estados de excepción psicológicos.

8 "Entre el año 2008 y 2010, España entró en una profunda recesión, llegando a caer un 3’7\% su PIB en 2009. La deuda pública española en 2013 ha alcanzado el 93\% del PIB, lo que se traduce en exactamente en 954.863 millones de euros. Por todo ello, la actividad económica en nuestro país ha sufrido una de las mayores convulsiones de las últimas décadas, siendo estos los efectos concretos de una crisis financiera global: desempleo, deuda, recesión y despoblación [...] La tasa de desempleo ronda los 6 millones de parados, entre el 25\% y el 27\% de la población activa. La tasa de paro juvenil supera el $57 \%$ y más de 100.000 jóvenes con formación universitaria han salido del país; las cifras son escandalosas: solo en tres años, 36.967 personas en 2010, alrededor de 51.140 personas en 2011 y 59.724 personas en 2012 han abandonado el país para buscar trabajo en el exterior; se calcula que alrededor de 225.000 personas han abandonado España durante todo el período de crisis económica"(Martínez Rubio, 2014: 47-50). 
Ahora bien, ¿qué sucede durante el estado de shock? ¿Hay algún tipo de reacción o la ciudadanía sufre las privatizaciones sin mostrar una voluntad adversa? Podría decirse que durante la crisis, España se ha convertido, al mismo tiempo, en el lugar de las privatizaciones y las manifestaciones. Una parte de la población ha ido reaccionando paulatinamente hasta generar datos como el que anunciaba el periódico El Mundo en el año 2013: "El primer año de Gobierno de Mariano Rajoy se saldó con más de 36.000 manifestaciones y concentraciones en toda España, sin contar las celebradas en el País Vasco, lo que supone una media diaria de casi 120 protestas". Las protestas más férreas y continuadas tuvieron lugar a partir del 15 de mayo de 2011 con el surgimiento de determinados colectivos y plataformas que lideraban y reunían a todo aquel que quería oponerse a las privatizaciones del gobierno: Democracia Real Ya, Spanish revolution, Movimiento 15-M, Primavera Valenciana y un largo etcétera de movimientos complementarios que fueron expandiéndose por todas las ciudades del país en busca de una reacción que frenase el shock $^{9}$.

Ahora bien, ¿qué significan estas reacciones en cadena que se oponen a la inmovilización que provoca un estado de shock? Afirma Martínez Rubio: "El 15-M, en principio, fue eso: una protesta. Y a esa protesta muchos le pedimos en su momento concreción de ideas. Nos equivocamos radicalmente. Deberíamos haberlo entendido como síntoma, no como fuerza de choque contra ningún partido" (Martínez Rubio, 2014: 50). Las reacciones (ya sea a través de manifestaciones o convocatorias de asambleas por medio de redes sociales) son síntomas de un despertar, son precisamente la muestra de que no nace solo una oposición a las privatizaciones que genera el sistema neoliberal, sino que nace exactamente una nueva subjetividad, una nueva forma de entender las relaciones gubernamentales y sociales.

Además, estas nuevas luchas sociales pusieron en tela de juicio otro de los elementos centrales del imaginario político español, lo que Amador Fernández-Savater denomina el 'estadocentrismo': "un tipo de mirada que pone el poder político en el centro de las preocupaciones, las expectativas y los deseos de cambio social. [...] La mirada estadocéntrica ve el poder político como causa-motor-fuente de los cambios sociales" (Fernández-Savater, 2014). Lo que supone la aparición de movimientos como el 15-M es

\footnotetext{
${ }^{9} \mathrm{La}$ aparición de movimientos sociales como el 15-M tuvo su origen en una reacción espontánea de la ciudadanía que pretendía conseguir una serie de objetivos concretos: "El 15-M es un movimiento apartidista y asindicalista que se organiza en torno a asambleas descentralizadas por los barrios de las ciudades de toda España [...] El 20 de mayo, la asamblea de la Puerta del Sol, en Madrid, elaboró un texto programático en un ejercicio de consenso entre todos los indignados allí reunidos"(Martínez, 2013) y donde se reclamaba, entre otras cosas: "Cambio de la Ley Electoral, atención a los derechos básicos y fundamentales recogidos en la Constitución, abolición de las leyes y medidas discriminatorias e injustas, reforma fiscal favorable para las rentas más bajas, reforma de las condiciones laborales de la clase política para la abolición de sus sueldos vitalicios, rechazo y condena de la corrupción, medidas plurales con respecto a la banca, reducción del poder del FMI y del BCE, desvinculación verdadera entre la Iglesia y el Estado, democracia participativa y directa, verdadera regularización de las condiciones laborales, cierre de todas las centrales nucleares y la promoción de energías renovables y gratuitas, recuperación de las empresas públicas privatizadas, total transparencia de las cuentas y de la financiación de los partidos políticos como medida de contención de la corrupción política"(Propuestas aprobadas día 20 de mayo de 2011).
} 
precisamente un desafío a esa "definición neoliberal de la realidad (un NO) y la producción de nueva realidad (un Sí)” (Fernández-Savater, 2014). Ese cuestionamiento del estadocentrismo supuso, por tanto, la emergencia de una nueva calidad de las luchas sociales, pero sobre todo el rechazo a una determinada forma de entender lo político y la penetración del neoliberalismo en las relaciones humanas: "el yo como empresa, la búsqueda de beneficio como motor de los comportamientos, la competencia como principio de relación con el otro, la propiedad y el consumo como medidas de la riqueza y la buena vida, el mundo como conjunto de oportunidades a rentabilizar" (FernándezSavater, 2014).

Este cuestionamiento de la realidad impuesta por el neoliberalismo, ese darse cuenta del shock producido, hizo que el Movimiento 15-M se fuese extendiendo hasta la actualidad dando forma a otras reivindicaciones de esa nueva subjetividad emergente, por ejemplo a través de colectivos como las Mareas ${ }^{10} \mathrm{o}$ la $\mathrm{PAH}^{11}$ :

Las plazas fueron una experiencia de cooperación entre desconocidos, donde los otros no eran instrumentos u obstáculos, sino cómplices e iguales. Una experiencia de anonimato, donde se disolvieron las clasificaciones y las identidades que establecen a diario quién es quién y quién puede qué. Una experiencia de activación, donde nos descubrimos capaces de hacer cosas que generalmente delegamos. Una experiencia de lujo y disfrute, donde la abundancia del tiempo y las relaciones, junto con el cuidado de la vida colectiva, se convirtieron en la verdadera medida de la «riqueza» y la «buena vida». Una experiencia, en fin, de intensificación de la dimensión común de la existencia (Fernández-Savater, 2014).

En conclusión, la crisis española es una de las representaciones del estado de shock neoliberal tratado por Naomi Klein y su desarrollo ha ido propiciando la emergencia no solo de nuevas subjetividades, sino también de movimientos sociales y luchas contestatarias que, en algunos casos, llegan hasta el terreno artístico.

\footnotetext{
${ }^{10}$ La Marea Ciudadana (antiguamente: Mareas Unidas) es una plataforma que aúna las distintas mareas ciudadanas: Marea Blanca (en defensa de la Sanidad Pública), Marea Verde (en defensa de la Educación Pública), Marea Roja (Movimiento Ciudadano de Desempleados en Lucha), LA PAH (Plataforma de Afectados por la Hipoteca), Marea Naranja (en defensa de los Servicios Sociales) y Plebiscito Vinculante (Acción que pretende constatar mediante una votación popular la opinión soberana de la ciudadanía ante decisiones que repercuten en el interés general de la población). ${ }^{11}$ La Plataforma de Afectados por la Hipoteca o PAH es una asociación y movimiento social por el derecho a la vivienda digna surgido en febrero de 2009 en Barcelona y presente en toda la geografía española con diversos nombres: Plataforma d'Afectats per la Hipoteca, Hipotekarengatik Kaltetutakoen Plataforma, entre otros. Esta asociación surge a raíz del desahucio de miles de familias españolas tras la quiebra de entidades bancarias e inmobiliarias.
} 


\title{
1.4. El shock estético
}

\author{
"La necesidad de exponerse a efectos de choque es \\ una acomodación del hombre a los peligros que le amenazan"
}

(Benjamin, 1989: 17)

El concepto de shock ha sido también central en el ámbito estético para referir a una de las operaciones básicas del arte y las poéticas vanguardistas, pero con un sentido totalmente contrario al uso político del shock que Klein atribuye al neoliberalismo. En las poéticas vanguardistas el shock aparece como una herramienta estética e ideológica para romper el horizonte de expectativas de los receptores y por tanto como una estrategia de ruptura frente a las prácticas culturales convencionales. Las vanguardias parten, en su origen, de algunas características propias del ámbito militar que son aplicadas al plano estético:

La 'fuerza de choque' y la destrucción del enemigo', axiomas del concepto militar, se integraron a las vanguardias artísticas bajo el principio de una 'estética del shock', llena de impulsos agresivos, metáforas beligerantes o manifestaciones abiertamente militaristas (p. ej. futurismo). En un primer sentido la «estética del shock» aparecería ligada con todas aquellas corrientes o estilos que persiguen, a través de la la innovación, la provocación y el impacto, crear en el espectador una serie de reacciones e inquietudes inmediatas, bien sea por los mensajes transmitidos bien por el tipo de «lenguaje» empleado (Calderón Gómez, 2005).

Calderón Gómez señala que el impacto puede producirse tanto a través del plano del significado como del plano del significante, "de hecho en numerosos proyectos del arte contemporáneo la 'estética del shock'se desarrolla en los dos niveles" (2005) y todo ello se orienta siempre hacia un objetivo concreto: contraatacar la indiferencia del público y despertar su capacidad autorreflexiva y crítica con la obra y con sus propias condiciones de existencia: "de ser una apariencia atractiva o una hechura sonora convincente, la obra de arte pasó a ser un proyectil. Chocaba con todo destinatario" (Benjamin, 1989: 17). De esta manera, el enfoque vanguardista renueva "el marco convencional de las relaciones entre autor y espectador" (2005), convirtiendo al público en sujetos críticos y activos. Por ello, señala Peter Burger al hablar de la labor de las vanguardias y su intención de negar la realidad existente: "tal negación de sentido produce un shock en el receptor. Esta es la reacción que pretende el artista de vanguardia, porque espera que el receptor, privado del sentido, se cuestione su particular praxis vital y se plantee la necesidad de reformarla" (1987: 146).

Según María Cecilia Guerra, los efectos de shock en las vanguardias se manifiestan "en dos dimensiones complementarias de la experiencia" (Guerra, 2005: 10): por un lado, la ruptura de hábitos y expectativas con los que está familiarizado el espectador, es decir, la ampliación de horizontes en el plano de la realidad; el objetivo principal es generar nuevos sentidos -uno de los ejemplos fundadores será el conocido urinario público de Duchampde manera que "la obra se enclavará sobre un campo estético, cuyos actores - conocedores de las leyes de este campo--, lucharán para expandir los límites del arte, y para reunir la 
mayor cantidad de capital simbólico" (Guerra, 2005: 10). Por otro lado, la segunda dimensión de la experiencia que se ve afectada se relaciona directamente con la experiencia estética en tanto ruptura con los valores predeterminados que imponen las instituciones: "las vanguardias dictan la ley y esta ley está definida por una relación de negatividad con respecto a los valores ontológicos" (Guerra, 2005: 11). Lo que ocurre, por tanto, es que el objetivo primario de las vanguardias - "provocar la emergencia de realidades implícitas" (Burger, 1974: 9)- se lleva a cabo a través de los efectos de shock.

Ahora bien, esta idea de las estéticas del shock no es en realidad únicamente aplicable a la vanguardia, el propio Walter Benjamin, en el que todos estos autores se inspiran, ya utilizó el concepto de shock para referirse a la relación entre la poesía moderna y la experiencia urbana a finales del XIX. Así hablaba acerca de la poesía de Baudelaire: "La poesía lírica podría fundarse en una experiencia para la cual la recepción de shocks se ha convertido en la regla [...] Ello se adapta perfectamente a la poesía de Baudelaire" (1999: 7). En conclusión, cabe destacar la relación que Gómez destaca en su artículo entre el concepto de estética del shock y el concepto posteriormente trabajado por Naomi Klein de doctrina del shock:

El problema central de este tipo de procedimiento es que no sólo ha sido aplicado al campo de las artes y de la literatura, sino que constituye una de las herramientas esenciales de las «técnicas modernas de control social». Así, el sometimiento continuo de los individuos a grandes cantidades de estímulos [...] va condicionando en los sujetos una disposición «favorable» respecto a la manipulación política y comercial y una estructura cognitiva carente de capacidad reflexiva (2005).

Se trata, por tanto, de dos concepciones totalmente diferentes del shock. El shock vanguardista tiene como misión despertar al sujeto (lector, espectador) de su indiferencia mediante un extrañamiento radical que de alguna forma le haga cuestionarse sus condiciones de existencia y la automatización de su percepción. Por el contrario, el shock del capitalismo del desastre del que habla Klein tiene como objetivo anular la capacidad crítica del sujeto, cortar su relación con la historia e incapacitarle para reflexionar críticamente sobre los procesos que está viviendo. Si el shock político busca la manipulación de la ciudadanía, su sumisión total a los intereses del poder económico, el shock estético de las vanguardias tiene un potencial liberador o al menos así se plantea en su origen. 


\subsection{Las poéticas del shock}

${ }_{\mathrm{C}}$ Es posible conciliar estas dos concepciones del shock para hacer referencia a una realidad poética actual? El concepto de poéticas del shock ${ }^{12}$ que se propone en este trabajo es precisamente un intento de redefinir el concepto de shock en el ámbito poético de un modo que no refiera solo a las técnicas del choque vanguardista, sino que incorporando la problemática política del neoliberalismo pueda dar cuenta de nuevas poéticas producidas por sujetos en estado de shock. Para caracterizar estas nuevas poéticas y su relación con los procesos sociales actuales es necesario pensar la influencia de la lógica neoliberal en el sistema poético. Para ello se aludirá a dos puntos fundamentales: por una parte, a la mercantilización de toda la producción cultural y por tanto también de la producción poética, y por otra, a la construcción de voces y sujetos poéticos que necesariamente entran en relación con las nuevas subjetividades del neoliberalismo.

En primer lugar, la poesía está sometida a las leyes del mercado neoliberal ${ }^{13}$, y por tanto los autores del sistema poético luchan por conseguir el capital económico, pero también el capital simbólico del que hablaba Bordieu ${ }^{14}$. Al entrar en la dinámica neoliberal de la empresa, también aceptan las leyes de la competitividad del mercado. El mercado editorial se fundamenta en una competición donde el capital decide las publicaciones actuales y designa al escritor útil en tanto sujeto neoliberal, generando también normas poéticas y tendencias estilísticas y literarias. Ahora bien, es preciso matizar que la decisión sobre lo que debe o no publicarse no solo depende del capital económico (beneficio económico por las ventas), sino también del capital cultural (prestigio, distinción, identificación de la élite diferenciada) que se enmarca, de nuevo, en un contexto de competición ${ }^{15}$. Este contexto de mercantilización no es algo nuevo en la poesía, pero sin duda, emerge en el neoliberalismo de forma más agresiva que en épocas anteriores.

El poeta ahora no solo pretende competir con el resto de producciones poéticas o literarias en general, sino también con la expansión de los medios digitales en auge. La adaptación al terreno virtual supone ampliar las posibilidades de adquirir capital (en los dos

\footnotetext{
${ }^{12}$ En sus trabajos sobre testimonio chileno, Jaume Peris Blanes (2005 y 2008) ha trazado una relación similar entre el shock del neoliberalismo, el trauma subjetivo y las escrituras posibles sobre la represión militar. En este trabajo desarrollaremos esa relación, pero no enfocada a textos testimoniales sino poéticos.

${ }^{13}$ Se necesitaría un estudio más amplio sobre esta cuestión que sobrepasa la extensión y los objetivos del presente artículo.

${ }^{14}$ A este respecto, agradezco y reproduzco el comentario de David Becerra, que proponía citar la obra Intelectuales de consumo de José Antonio Fortes donde "no solo se analiza la corrupción existente en los premios de poesía en España sino que además el libro recoge un catálogo de los distintos premios que se convocan, mostrando cómo en ellos siempre aparecen los mismos poetas en el jurado y en consecuencia solo se premian a poetas de la misma corriente o, más grave todavía, a aquellos poetas con los que el jurado comparte amistad. En la poesía, a diferencia de lo que ocurre con la novela, el mercado tiene un impacto mínimo; como la poesía apenas vende, el poco dinero que mueve es en los premios literarios. Como el botín es menor, la lucha es más encarnizada. Y de allí la alta corrupción."

${ }^{15}$ El concepto de capital cultural fue acuñado por Pierre Bourdieu en su obra La Reproducción publicada en 1973. El autor lo define como la acumulación de cultura propia de una clase que tiene más peso en el mercado simbólico cultural.
} 
sentidos) y, sobre todo, generar nuevas producciones poéticas, tal y como señalaba Charles Bernstein: poesía electrónica, poesía hipertextual, poesía auditiva, poesía visual, "dentro de las áreas de experimentación, se exploran las posibilidades de los medios técnicos como herramientas para la producción literaria. Entre los resultados obtenidos están la poesía generada por computadora, y la utilización del blogging para la creación" (Bernstein, 2006: 10). El mercado neoliberal, por tanto, sumerge al poeta en los mecanismos de competitividad y no solo conlleva que este se adapte a los nuevos medios de difusión (con qué difundir) sino que también genera tendencias y normas sobre cómo escribir poesía (cómo difundir): son cada vez más numerosos los talleres -virtuales o presenciales- para 'aprender a escribir poesía'.

Ahora bien, frente a las imposiciones del mercado neoliberal también pueden tener lugar manifestaciones poéticas que escapan a los espacios y a las regulaciones del capital. Precisamente la red y el espacio urbano se han constituido en espacios potenciales de resistencia en el arte y, por tanto, en la poesía. Así, los medios digitales se utilizan en muchas ocasiones no como instrumentos para competir sino como elementos para disentir. El uso de plataformas virtuales (blogs, redes sociales) puede suponer una alternativa negadora frente a las imposiciones de las editoriales -un modo de autogestión poética sin exigencias acerca de cómo ni con qué difundir-. El otro ejemplo de rechazo a la mercantilización poética surgió hace tan solo quince años y está representado por la denominada Acción Poética, un movimiento poético que gira en torno a la escritura de graffitis poéticos ${ }^{16}$.

Frente a la consagración del autor que tiene lugar en los procesos de mercantilización artística y poética, muchas de estas prácticas alternativas que pasan por fuera del sistema editorial replantean el concepto de autoría redefiniéndolo, haciéndolo borroso, e incluso a veces negándolo o haciéndolo colectivo (como en el caso de la Acción Poética). En ese gesto puede leerse una voluntad de disenso frente a la comercialización de la poesía y la figura que el autor desempeña en ella.

En segundo lugar, si el neoliberalismo también genera nuevas subjetividades, la poesía contemporánea puede entenderse como la construcción de voces y sujetos poéticos que necesariamente entran en relación con los nuevos sujetos emergentes. Al hablar de poéticas del shock se está haciendo referencia no a una técnica vanguardista sino a una característica del sujeto que habla: el sujeto escribe desde un estado de shock producido por la crisis económica de España (violencia del capitalismo y privatizaciones), de manera que construye voces poéticas que tienen los efectos de ese trauma. No se trata, por tanto, del shock de la modernidad que nutría a las vanguardias para conformarse en herramientas de resistencia, sino del shock traumático del neoliberalismo.

\footnotetext{
${ }^{16}$ Así se define en la web no oficial: "Acción Poética es un movimiento iniciado por Armando Alanis Pulido en 1996 y que redefine la poesía urbana como tal. El contenido de las frases son generalmente pensamientos de amor y frases optimistas, citas de poetas, escritores, músicos... Firmadas con el sello y formato de Acción Poética. Tiene quince años de existencia, Acción Poética está hoy presente en México, Argentina, Lima, Perú, Venezuela, España, y otros países de habla hispana".
} 
¿Qué supone el estado de shock en la poesía? ¿Es una forma de resistencia o es un elemento contra el que se actúa? Según Kamal Cumsille, siguiendo el estudio que Walter Benjamin realiza sobre la obra de Baudelaire, sugiere que la poesía de Baudelaire nace precisamente de su experiencia del shock poético, del duelo al que está sometido el artista entre la contención de lo traumático y el fracaso de dicha contención. De manera que, en Baudelaire, la experiencia del shock es el centro de su tarea artística:

El límite en el que se mantiene la experiencia poética, sería entre la contención del traumatismo por medio de la reflexión [...] y el fracaso de dicha contención, que Baudelaire fija con la figura del 'duelo' en el que se bate a sí mismo el artista durante el proceso de creación. 'Por lo tanto Baudelaire ha colocado la experiencia del shock en el centro de su tarea artística' (Kamal Cumsille, 2007: 3).

También estas poéticas del shock (que estudiaré a partir de tres libros actuales) colocan la experiencia del trauma en el centro de su tarea artística, la diferencia es que el trauma de Baudelaire nace de su propia dualidad como artista y todo el proceso creativo, mientras que esa experiencia traumática en la poesía actual nace del choque producido por las situaciones socio-históricas. La poesía no es solamente representación, sino también construcción de una voz y, en ese sentido, de un sujeto que habla en el poema. ¿De qué forma se inscribe ese sujeto poético en la dialéctica entre poder y subjetivación de la que hablaba Foucault? ¿Cómo se relaciona el sujeto de enunciación que se construye en el poema con esas nuevas subjetividades que el neoliberalismo produce? 


\section{Redefiniciones de lo político en la poesía: hacia las poéticas del shock}

Si el shock era un elemento de manipulación social empleado por el neoliberalismo $\mathrm{y}$, al mismo tiempo, un elemento de sacudida de la indiferencia social en el arte vanguardista, las poéticas del shock suponen la construcción de una voz poética -a partir de la herencia del shock vanguardista- que da cuenta de un sujeto herido por la violencia neoliberal. Lo político, por tanto, constituye desde esta perspectiva un elemento estructurante del sujeto poético independientemente de que el poema aluda temáticamente a la política o no ${ }^{17}$. Esta forma de plantear la relación entre lo político y la poesía hereda algunas de las problemáticas abordadas por la literatura en las últimas décadas. No en balde, la relación entre el lenguaje poético y la intervención social ha sido uno de los ejes estructurantes del debate poético precedente.

\subsection{El compromiso entre vanguardia y realismo}

La relación entre poesía y política ha sido, en las últimas décadas, uno de los elementos centrales en el debate sobre las poéticas contemporáneas (tanto para poner en duda esa relación como para afirmarla o convertirla en un elemento diferenciador entre creaciones literarias). De hecho, el sentido de esa relación (la poesía y lo político) ha sido uno de los factores fundamentales de conflicto que estructuran el campo de la poesía contemporánea española. Durante las últimas décadas ha habido estudios críticos que han disminuido la importancia del factor político en la producción literaria limitándose a trazar el panorama poético en relación con las distintas tendencias y elementos -tropos, temáticas, métrica, etc.-, mientras que, por otra parte, ha habido estudios críticos que han señalado esa importancia de lo político en la producción literaria para enfrentar poéticas de mayor o menor signo político.

Lo que subyace a la mayoría de esos estudios contemporáneos es una interpretación muy marcada de lo que 'debería ser la poesía' -ideas definidas sobre la relación con el medio, la naturaleza, la función y el valor del lenguaje poético-; es decir, en ellos se trasluce una ideología literaria que valora negativa o positivamente el elemento político que aquí nos atañe. Lo que sucede, no obstante, es que a pesar de la mayor o menor importancia que decida concedérsele al factor político en la poesía, lo cierto es que si se miran con detenimiento las batallas poéticas de las últimas décadas, se ve claramente cómo la forma de intervención política y social a través del lenguaje ha constituido uno de los puntos centrales de disputa entre las diferentes corrientes que se han disputado la hegemonía.

17 A nivel general, cabe diferenciar entre 'la política', entendida como el conjunto de prácticas ligadas a las instituciones de representación y de negociación parlamentaria, frente a 'lo político', entendido como el campo mucho más amplio de creación de relaciones sociales y constitución de las formas de vida en sociedad. Así lo define Chantal Mouffe siguiendo a Canetti: "Con ese fin propone (Canetti) distinguir entre 'lo político', ligado a la dimensión de antagonismo y de hostilidad que existe en las relaciones humanas, antagonismo que se manifiesta como diversidad de las relaciones sociales, y 'la política', que apunta a establecer un orden, a organizar la coexistencia humana en condiciones que son siempre conflictivas, pues están atravesadas por 'lo político"'(Mouffe, 1999: 14). 
Efectivamente, el campo de la poesía actual se sostiene sobre una intensa lucha por la hegemonía entre diferentes ideologías poéticas; es decir, podemos llegar a entender la historia de la poesía reciente como una sucesión de hegemonías y, concretamente, lo relevante para el presente trabajo es que cada nueva hegemonía se ha construido, en su origen, como una rebelión contra la hegemonía poética anterior. "Cada ruptura es un comienzo" (1972: 3) dirá Octavio Paz. Un ejemplo clarificador de este movimiento de rebelión-hegemonización sería el caso de la poética de Luis García Montero, que será tratada con más profundidad en el apartado siguiente: García Montero, partidario de una poesía realista o figurativa, se 'rebela' contra la poesía de signo vanguardista 'hegemónica' en los años setenta y principios de los ochenta y tras destituirla termina erigiendo su poesía realista en la 'hegemonía presente'.

No obstante, la actual hegemonía de las poéticas de la experiencia se sostiene en una afirmación discutible: la del alejamiento de la realidad de la poesía vanguardista y la de la necesidad de volver a la realidad que las poéticas figurativas postulaban como modo de recuperar una cierta idea del 'compromiso' en literatura que la experimentación de los sesenta y setenta habrían olvidado. Aquí entra en juego lo que destacan varios críticos y escritores, entre ellos Josu Montero: "Primer error: asociamos poesía comprometida con poesía realista, figurativa" (2003: 6). ¿ ¿Solo la poesía realista puede ser una poesía

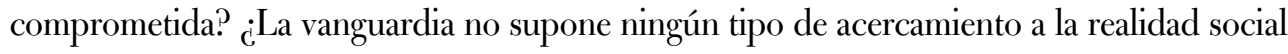
ni puede erigirse como un tipo de escritura política?

No se trata de un debate nuevo. Desde hace décadas la lucha entre ideologías literarias que pugnan por la hegemonía ha sido conceptualizada fundamentalmente en torno a la oposición entre poéticas realistas y figurativas y poéticas herederas de la tradición vanguardista, que se disputan el significado del significante compromiso $^{18}$. A esa disputa aludió Claudia Gilman al analizar los dilemas de la escritura literaria en el contexto revolucionario de los años sesenta latinoamericanos ${ }^{19}$ :

Los defensores del compromiso de la obra en clave realista acentuaron el poder comunicativo y la influencia de la obra de arte sobre la conciencia de los lectores. Los defensores de la tradición de la ruptura [vanguardistas] afirmaban la paridad jerárquica de la serie estética y la serie política; planteaban como su tarea la de hacer 'avanzar' el arte del mismo modo que la vanguardia política hacía 'avanzar' las condiciones de la revolución, y también formulaban que el compromiso

18 Sin duda, la utilización recurrente de la palabra compromiso ha derivado en un desgaste y manipulación de su significado que hace especialmente difícil y problemático su uso en la actualidad.

19 Claudia Gilman estudia concretamente una de las fases más duras de la politización de los intelectuales donde dos figuras universalmente conocidas como Julio Cortázar y el Che Guevara representaban respectivamente la escritura en clave vanguardista y la escritura en clave realista disputándose la apropiación del compromiso con el pueblo. De manera que mientras Cortázar lo hacía a través de la experimentación del lenguaje y la ruptura de las formas lingüísticas implantadas por las instituciones dominantes, el Che y otros escritores del periodo defendían una poética testimonial, al margen de experimentaciones, que conectara de manera directa con el pueblo (Gilman, 2003). 
artístico-político implicaba la apropiación de todos los instrumentos y conquistas del arte contemporáneo (Gilman, 2003: 144).

Sin duda, los conceptos de 'realismo' y 'vanguardia' han sido sometidos a una continua redefinición a lo largo del s. XX y el s. XXI, pero al igual que hace Gilman, podemos concebirlos, de un modo general y abarcador, como dos formas diferentes de relación con el lenguaje. Por un lado, la vanguardia entendida como aquella producción poética cuya fuerza reside y se justifica en la experimentación con el lenguaje ${ }^{20}$, cuyo objetivo es destruir las formas consolidadas y experimentar con posibilidades nuevas del código. Por otro lado, la escritura realista funciona basándose en una idea de 'figuración' que no violenta los códigos establecidos porque entiende que solo de esta forma, usando un lenguaje conocido, podrá llegar a crear una comunicación con el lector.

De acuerdo a la oposición de Gilman, la clave realista concibe el compromiso como la forma de establecer un diálogo directo con sus lectores y para ello no entrará a cuestionar el lenguaje, sino todos los planos de la realidad, que considera plenamente inteligible. Por ello, desplazará su foco de atención desde el lenguaje hasta el público lector, haciendo de la comunicabilidad uno de sus principales objetivos.

Por el contrario, las lecturas políticas del vanguardismo apostarán por la ruptura radical de las normas lingüísticas establecidas por las instituciones dominantes y propondrán la idea de una subversión lingüística, es decir, romper con la violencia del lenguaje o tal y como afirma el título del artículo de Miguel Casado "Hablar contra las palabras": se debe hablar contra las palabras en un proceso de deconstrucción y construcción posterior porque estas han nacido bajo el amparo del neoliberalismo y el sistema capitalista, por lo que arrastrarán consigo la carga socio-histórica y los prejuicios o limitaciones del mundo contemporáneo. Según esta concepción, el capital se ha apropiado de la lengua y las prácticas vanguardistas, al deconstruirla, están cuestionando y quebrando las versiones hegemónicas de la realidad. Ya hace más de ochenta años que César Vallejo habló del agotamiento de contenido social de las palabras en el capitalismo, y de la necesidad de una refundación del lenguaje en la poesía para poder reconstruir ese vínculo del lenguaje y la comunidad que el capitalismo habría quebrado ${ }^{21}$.

20 En su obra Sobre la violencia. Seis reflexiones marginales, Žižek hablará del lenguaje como un elemento catalizador de dos fuerzas contrarias: por un lado la libertad del lenguaje entendida como posibilidad de pensamiento y por otro lado la violencia del lenguaje en tanto elemento que aglutina la subjetividad de las instituciones dominantes (Žižek, 2009).

21 "El agotamiento de contenido social de las palabras. E1 verbo está vacío. Sufre de una aguda e incurable consunción social. Nadie dice a nadie nada. La relación articulada del hombre con los hombres, se halla interrumpida. El vocablo del individuo para la colectividad, se ha quedado trunco y aplastado en la boca individual. Estamos mudos, en medio de nuestra verborrea incomprensible. Es la confusión de las lenguas, proveniente del individualismo exarcerbado que está en la base de la economía y política burguesa. El interés individual desenfrenado-ser el más rico, el más feliz, ser el dictador de un país o el rey del petróleo-, lo ha colmado de egoísmo todo hasta las palabras. El vocablo se ahoga de individualismo. La palabra - forma de relación social la más humana entre todas-ha perdido así toda su esencia y atributos colectivos"(1931:13). 
Así pues, uno de los objetivos posibles de la vanguardia poética es romper con esas estructuras de poder que están presentes en el lenguaje: "vivimos por fuerza dentro de un mundo de palabras que está dado y que, al usarlas [...] se expresa el poder, el sistema que nos domina e implica [...] La conclusión de Ponge es [...]: "hablar contra las palabras"” (2003: 38). Se trata de una escritura que pretende evitar la denominada servidumbre voluntaria del sujeto de la que hablaba Beauvois22; es, al fin y al cabo, una poesía antidisciplinaria, en el sentido foucaultiano, que trata de liberar al sujeto de los elementos de poder que se han inscrito en él.

Podría decirse, pues, que la vanguardia entiende el compromiso como un movimiento desde dentro hacia fuera, es decir, que se apoya en el desmoronamiento de las instituciones dominantes desde dentro, desde el lenguaje, y ello explicaría la constante recurrencia a autores como Foucault (el problema reside en la realidad, hay que desmontar esa realidad que está dada a partir de su cuestionamiento y volver a formularla: "el mundo no es ni podrá ser completamente transparente" (Riechmann, 2003: 22); mientras que la clave realista entiende el compromiso como un movimiento de diálogo entre dos superficies, la del poeta y la del ciudadano, de manera que comprometerse consistiría en ser capaz de establecer ese diálogo para que el ciudadano tomase conciencia de la realidad ${ }^{23}$. Dos movimientos, por tanto, diferenciados por la dirección de sus formas de actuación y sus concepciones de la realidad como espacio plenamente inteligible (realistas) o como espacio de problematización de los lenguajes (vanguardistas).

Estas lecturas contrapuestas del compromiso en clave de 'vanguardia' y 'realismo' han sido redefinidas y renombradas constantemente en la literatura española en las últimas décadas, dando lugar a una multiplicación de las etiquetas y categorías explicativas que desarrollan, a partir de oposiciones binarias, esa dicotomía central entre las interpretaciones de la capacidad de intervención social del poema. Así lo demuestra por ejemplo, Jorge Riechmann (2003) al hablar de un tipo de poesía que indaga a través del lenguaje (poesía vertical y poesía de indagación equivalente a vanguardia) junto a un tipo de poesía que testimonia y que, para ello, establece el contacto directo con el mundo, con los lectores en general (poesía horizontal y poesía de testimonio equivalente a realismo) ${ }^{24}$.

22 Prólogo al Tratado de la servidumbre liberal, de Jean-léon Beauvois, "Beauvois y la libertad leninista"de Slavoj Žižek (2008): "Esto es especialmente aplicable hoy, en la era de lo que sociólogos como Ulrich Beck denominan la "sociedad del riesgo", cuando la ideología dominante se esfuerza por vendernos la mismísima inseguridad causada por el desmantelamiento del Estado del bienestar como la oportunidad de alcanzar nuevas libertades [...] cuando esto se inscribe en la ideología del sujeto entendido como individuo psicológico preñado de habilidades y tendencias naturales, entonces por así decirlo interpreto todos estos cambios como resultado de mi personalidad, no como resultado de que las fuerzas del mercado me arrojen de un lado a otro". La citación carece de página porque el prólogo ha sido consultado online en la referencia virtual que aparecerá en la bibliografía.

${ }^{23} \mathrm{Y}$ así, por ejemplo, lo define un poeta actual como Jorge Riechmann: "Gracias a una traducción incorrecta: "compromiso"se dice en italiano impegno, que podemos "retraducir"al castellano como empeño. Empeño quiere decir para mí, hoy y aquí: no mentir y no aumentar el sufrimiento del otro"(2003: 21).

${ }_{24}$ Poesía vertical, decía el gran Roberto Juarroz: esa dimensión que traza la línea directa entre el corazón y la estrella, la palabra que indaga en el revés del mundo; pero también la otra dimensión, 
También Joan Oleza (2008) redefine esta oposición remontándose a la obra $S / Z$ de Roland Barthes: habla acerca de textos lisibles en tanto creaciones que no transforman los códigos establecidos, igual que ocurre con los textos realistas, frente a textos scriptibles en tanto rompedores de la comunicación para fomentar una reescritura por parte del lector, tal y como ocurre con los textos vanguardistas ${ }^{25}$.

Esa amplitud terminológica demuestra que la lucha contemporánea entre poéticas en el panorama español ha estado protagonizada por dos corrientes cuyas etiquetas deben manejarse con precaución: poesía de la experiencia frente a poesía del silencio, poesía figurativa frente a poesía abstracta o experimental, poesía realista frente a poéticas de lo real; todas esas oposiciones que articulan el debate poético contemporáneo remiten, en última instancia, a esa diferente posición ante lo poético que aparece en la disyuntiva entre las claves de lectura realista y vanguardista de la idea de compromiso.

\section{2. Claves del panorama actual}

La sucesión de hegemonías en torno al concepto de compromiso cristaliza en el panorama poético actual y desemboca en las poéticas del shock. Joan Oleza señala que en la España de los años sesenta y setenta se generó una hegemonía vanguardista que estaba representada por el tridente que formaban los novelistas de los años 50, los novísimos y la figura de Juan Benet, apoyados por la labor editorial de Carlos Barral y la obra crítica de Josep María Castellet. Todos ellos se erigieron en el panorama español como los representantes del discurso dominante de signo vanguardista (desde una perspectiva crítica, narrativa y poética): "Todo lo real era susceptible de sospecha. [...] Reproducían miméticamente todos ellos los postulados del postestructuralismo francés: nos envolvía por todas partes el lenguaje de Barthes, la escritura de Derrida, los discursos de Foucault" (Oleza, 2008: 8). Sin embargo, esta hegemonía vanguardista comenzó su proceso de estancamiento cuando empezó a convertirse en un instrumento más del sistema capitalista donde la alta producción y la constante competitividad llegaron a derivar en la comercialización vanguardista: "la Vanguardia, podríamos prolongar a Bürger, forma parte hoy de la cultura del supermercado y las estampaciones del Guernika se venden no muchos estantes más allá de las muñecas Barbie" (Oleza, 2008: 17). Si la vanguardia fue en su

esa poesía horizontal que se sabe compañera de todo lo existente, esa palabra que da testimonio de lo que pasa en el mundo [...] Hay en efecto poemas que son preguntas sin fin hacia lo abierto; pero también poemas (o textos literarios cercanos a poemas, si nos ponemos juanramonianos ortodoxos) que son testimonio de lo que nos pasa. Creo que ambas laderas son necesarias. (Ya dije antes que he empleado la distinción poesía vertical/ poesía horizontal para referirme a esto mismo.) Se podría hablar, también, de poesía de indagación y poesía de testimonio (Riechmann, 2003: 18-20).

25 Por no poner más que un ejemplo, en $S / Z(1970)$, el libro pontifical de la crítica literaria del final del milenio, Roland Barthes distinguía dos tipos de texto según su relación con la doxa o norma lingüística. De un lado estaban los textos lisibles, los que se conforman con los códigos establecidos, aquellos en los que el lector consume pasivamente el significado inscrito en el texto, los que comunican su contenido. Del otro lado quedaban los textos scriptibles, los que confrontan al lector con lo insólito, lo incomprensible, los que rompiendo la comunicación incitan al lector a reescribir el texto (Oleza, 2008: 11). 
origen un ataque al arte como institución ${ }^{26}$, la institucionalización y la industrialización del arte vanguardista suponen la constatación de su fracaso como proyecto disruptivo. Los primeros signos de esa institucionalización marcaron, de hecho, su declive como práctica cultural antagonista ${ }^{27}$.

Este declive vanguardista favoreció la reformulación del concepto de compromiso en el arte desde una nueva versión de la clave realista, que disentía del objetivo primario de la vanguardia ("provocar la emergencia de realidades implícitas"), tal y como lo define Peter Burger:

La vanguardia subraya la mediación del sistema artístico en el conocimiento de la realidad. Con ello critica el principio romántico de la inmediatez, la transparencia al sentimiento que caracteriza a los expresionismos. El arte es intransitivo, no es un medio para difundir o expresar emociones o juicios ajenos al proceso de su realización: se trata de una lente activa que deforma la visión de las cosas de acuerdo con las peculiaridades de su propia consistencia (1974: 9).

Ese cuestionamiento de los principios vanguardistas fue especialmente fuerte en el campo de la poesía española de los años ochenta, iniciado por algunos críticos y narradores de la denominada literatura 'figurativa', de modo que la poesía comienza a plantearse un tipo de compromiso en tanto que muestra directa de la realidad, sin modificar el código lingǘstico para poder ser entendida por todos sus lectores.

Por todo ello, el cambio latente en poesía se materializa en 1983 cuando se publica en el periódico nacional El País un artículo titulado "La otra sentimentalidad" donde Luis García Montero (junto al grupo granadino compuesto por Álvaro Salvador y Javier Egea) lleva a cabo ese movimiento de rebelión realista frente al sistema poético establecido en ese momento: "en esencia, el artículo venía a reprochar a la norma poética dominante su sacralización del yo privado y a apostar por otra sentimentalidad [...] la poética de Luis García Montero vino a chocar frontalmente con el discurso modernista, el de la canonización de la vanguardia" (Oleza, 2008: 2-10) ${ }^{28}$. La intención, por tanto, era convertir

${ }^{26}$ Esta es la tesis principal que expone Peter Burger en su ensayo Teoría de la vanguardia (1974) y que ha sido estudiada recientemente por Alejandra Soledad: "[Peter Burger] sostiene que lo que define a la vanguardia es su ataque a la institución arte. Este último tópico hace referencia a las formas en que el arte se produce y circula en las sociedades burguesas modernas y a las ideas que rigen el consumo en ese contexto. Parte de un proceso de autonomización de la cultura occidental: el arte, como otras actividades, se fue independizando culminando en el siglo XIX con teorías paradigmáticas como las de l'art pour l'art que alejaban al arte de la praxis vital. Ese fue uno de los cardinales principios contra los cuales la vanguardia se rebeló, intentando reconducir el arte a la vida"(Soledad, 2008: 2).

27 "La vanguardia como metáfora bélica supone la organización del "campo de batalla"en dos bandos; resultará de ello un vencedor y un vencido. Los movimientos de agitación estética surgieron como reacción a la guerra; como respuesta negativa y violenta a un orden hegemónico. Este movimiento reactivo por el que se fundaron, limitó su capacidad de comprensión dialéctica; donde hay reacción no hay preguntas. Se esperaba salir victorioso o muerto de aquella guerra cultural. Por ello, terminaron sin más remedio entre las alternativas de autodisolverse o volverse opacadas por el mismo sistema que pensaban destruir"(Cecilia Guerra, 2005: 11).

${ }^{28}$ Luis García Montero (1983: 9), "La otra sentimentalidad": "Pero las cosas cambian, ya se sabe, al ritmo de la historia. En una sociedad fuertemente industrializada no existe un lugar cómodo para 
a esta nueva versión del realismo en la poética hegemónica y conseguir así "recuperar la dimensión pública de lo privado, devolver lo individual al seno de la realidad colectiva y de la historia" (Oleza, 2008: 14). Se habla de una nueva versión del realismo porque, extrapolando la cita de Josu Montero en la que hace referencia a la poesía de Jorge Riechmann, en este tipo de realismo se usa la palabra despojada de la visceralidad de la poesía social precedente: "supliendo con la ironía lo que era, entonces, desmelenamiento e ira" (Montero, 2003: 9).

Lo que sucede, entonces, en el panorama poético español, es el proceso enunciado anteriormente de rebelión-hegemonización: esa poética que en los años ochenta apareció como una rebelión realista frente a la institucionalización de una vanguardia cada vez más solipsista, llegó a consolidarse en los años siguientes como una nueva hegemonía, si cabe más violenta que la anterior. Lo que se disputó en la lucha poética de hegemonías que terminó con la victoria de 'la otra sentimentalidad' fue la imposición de una significación concreta de compromiso que buscaba "la fórmula que acabe con nuestras propias miserias" (García Montero, 1983). Durante las últimas dos décadas, la consolidación de la llamada 'poesía de la experiencia' como discurso dominante en el campo poético español ha tenido lugar a través de varios instrumentos: sistema de premios, editoriales, crítica, periódicos. Podría llegar a hablarse de una omnipotencia poética realista sustentada en esa necesidad (del lector y, por tanto, de todo el sistema comercial) de hacer visible la realidad, que ellos consideran inteligible y representable.

No obstante, también esta poética de signo realista se encuentra con una poética rebelada frente a ella, que lucha por defender la noción vanguardista sobre el concepto de compromiso. Una de las oposiciones más destacadas será la que presente el colectivo Alicia Bajo Cero, articulado en 1993, cuya intención primaria se define claramente en la frase de Arnold Hauser que encabeza uno de sus artículos: "El criterio de la fecundidad de un arte comprometido no estriba en la solución de crisis y conflictos, sino en combatir la ilusión de que, en medio de los peligros y bajo el signo de la catástrofe, todavía se sigue viviendo en un mundo sin peligro alguno" (Colectivo Alicia Bajo Cero, 1997: 23). Este colectivo, junto a otras poéticas rebeladas, recuperan algunos presupuestos vanguardistas:

Se recupera también un elemento fundamental de la epistemología de la vanguardia, esa voluntad de hablar en dirección de la ausencia, de la que hablaba por ejemplo Foucault (1996: 122). Se trata de llevar el lenguaje a su límite, hacerlo apuntar hacia un más allá que señala el hueco de lo real en tanto indecible, en tanto rumor sordo que corre por debajo del lenguaje y del que sin embargo procede la angustia (Jesús Peris Llorca, 2014: 25).

El propio Méndez Rubio hablará de la función de la poética en clave vanguardista no como una relación directa con lo real (tal y como pretende García Montero), sino como

los asuntos gratuitos, es decir, para las prácticas que no tienen una utilidad inmediata. Dentro de las ciudades modernas los poemas se han visto abocados al ruidoso carnaval de la marginación, construyendo con su propia miseria su grandeza. Gentes extrañas, ciudadanos al margen del utilitarismo social del lenguaje, los poetas apostaron por sus peculiaridades, haciendo de la literatura un ideal de vida, y en consecuencia, del vitalismo, una de las características fundamentales de la poesía moderna." 
una relación conflictiva que haga a los lectores ser proclives al cuestionamiento de lo evidente. "Y es que "la vanguardia significó dos cosas: conciencia crítica del mundo y conciencia crítica del lenguaje", en palabras de Eduardo Milán (2004: 108), y estos son dos de los gestos fundantes de estas escrituras" (Jesús Peris Llorca, 2014: 8) ${ }^{29}$. En palabras de Méndez Rubio: "concibo la poesía al otro lado de esa privatización turística de lo visible" (2002).

La oposición, las poéticas rebeladas frente a la hegemónica poesía 'figurativa', denuncian esa voluntad de representar la realidad como un elemento plenamente inteligible y desacreditan uno de sus gestos más característicos: el lector debe sentirse aludido con esa representación de la realidad (como afirmaba García Montero en el año 93: "con el disfrute personal de quien se siente a gusto con unas páginas que en última instancia han de decirle: De te fabula narratur, aquí se habla de ti"); por ello, el colectivo Alicia Bajo Cero afirma: "suponer que el mayor interés de la parte receptora se centra en que se hable de ella en tanto individuo concuerda con la estrategia publicitaria del halago y la creación de un sentimiento narcisista" (1993: 4).

De manera que la realidad poética de los últimos años representa una vez más esa lucha de rebelión-hegemonización, pero esta vez no es Luis García Montero el rebelado, sino las nuevas poéticas de signo vanguardista las que se rebelan contra su hegemonización. Ahora bien, ¿qué lugar ocupan en este panorama los poetas jóvenes que se estudian en el presente trabajo? ¿Qué función cumplen dentro de la controversia heredada de una larga tradición literaria? Tal vez sea pronto para enmarcarlos dentro de la lucha entre el canon y el contracanon, pero resulta inevitable hablar sobre ellos en tanto víctimas de un shock político actual y productores de un shock estético.

${ }_{29}$ El artículo todavía está siendo evaluado por una revista para su posterior publicación. 


\section{Los versos del shock}

El primero de los tres libros que van a ser analizados recibe el título de Tenían veinte años y estaban locos (2011), coordinado por Luna Miguel, editado por Alejandra Vanessa y Elena Medel en La Bella Varsovia y cuya portada fue diseñada por Betty Blue.

\section{Tenian veinte años y estaban locos}

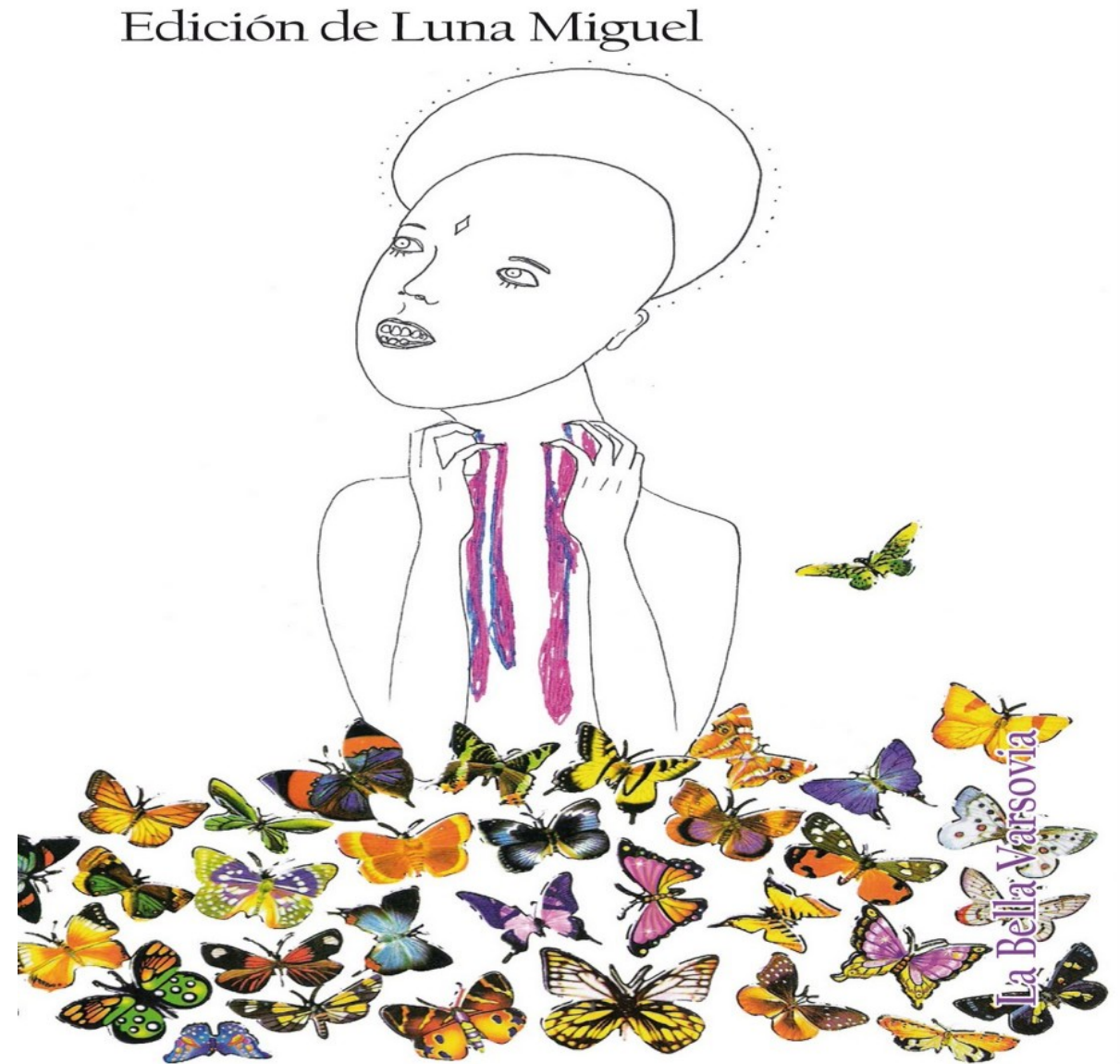

Reúne a veintisiete poetas menores de veintisiete años a través de un procedimiento emergente, la puesta en común de poemas en el soporte virtual (blog) de Luna Miguel, en diciembre de 2010:

Como sabéis, en diciembre de 2010 abrí el blog Tenían veinte años y estaban locos en donde más de cien poetas de todo el mundo han ido publicando sus poemas [...] El blog me sirvió para conocer a muchos autores muy desconocidos en aquel entonces, pero muy buenos, que merecían sin duda ser leídos y publicados. En primavera escribimos a estos autores y les propusimos aparecer en el libro-analógico de La Bella Varsovia (Luna Miguel, 2011: 9-19).

Esta obra reúne a "voces muy distintas, inquietudes muy distintas y trayectorias muy distintas" (Luna Miguel, 2011: 9-19) con el único propósito de dar a conocer la poesía que están escribiendo algunos jóvenes en España. El libro colectivo de Luna Miguel "aúna una 
diversidad de poéticas realmente independientes" (Jorge Díaz Martínez: 2011)30 sin proponer ningún programa estético o cambio concreto, "simplemente señala la natural alternativa generacional mediante la anunciación de una nueva hornada de poetas prolíficos y calientes [...] No es diferenciadora, sino integradora. Tampoco es pretenciosa, se anuncia como lo que es: simplemente un catálogo de nuevas voces frescas" (Jorge Díaz Martínez: 2011).

El principal elemento que reúne a los veintisiete poetas bajo este libro colectivo es "su pertenencia a una generación que ha crecido (nacido, casi) teniendo la world wide web como medio natural de comunicación" (Jorge Díaz Martínez: 2011); todos ellos han sabido poner en práctica los conocimientos sobre soportes técnicos que parecen intrínsecos a su generación para traspasar su producción poética del papel a la pantalla y así encontrarse. Este fenómeno cada vez más en boga y que ha sido tratado en la obra anteriormente citada de Charles Bernstein permite redefinir tanto el concepto de autoría como el concepto de obra en sí. El soporte virtual hace que el autor se diluya en su colectividad.

Los define Nuria Azancot en El Cultural de la siguiente manera: Son "autores que luchan en la calle, en la red y en el papel con la poesía como estandarte". Que apuestan "por la ironía, el visceralismo, la sentimentalidad; el gusto por el ritmo, los idiomas, la forma y, por supuesto, el respeto a la poesía más clásica" (Azancot, 2011) ${ }^{31}$. Tenían veinte años y estaban locos es una obra que, a diferencia de Calle de las impertinencias, no nace con un propósito político marcado, pero sin embargo son todos ellos también víctimas del estado de shock en tanto ciudadanos y en tanto receptores asiduos de información (ya sea virtual o analógica). La declaración de intenciones de este libro colectivo ya queda de manifiesto en el título que los recoge y que surge, tal y como explica Luna Miguel, de un poema de Roberto Bolaño (y que da título a su libro Los perros románticos, de 1998):

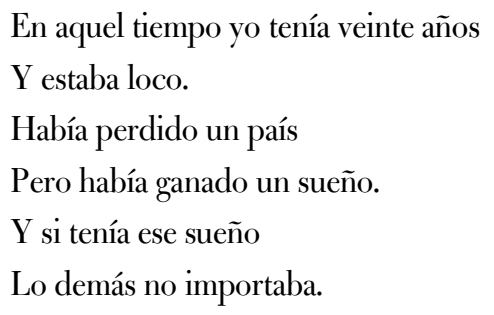

Parece, por tanto, que todos ellos también hayan "perdido un país" al mismo tiempo que "han ganado un sueño", el sueño de la poesía que se reúne mientras España se transforma:

Eran veintisiete poetas menores de veintisiete años que irrumpieron en la poesía regenerando con sus versos e invocando tiempos nuevos. Porque en este tiempo difícil para la juventud, minado por el desconcierto y la indignación, sólo la Literatura y Su Literatura pudo traer un poco de esperanza. Eran poetas. Eran hermosos. Estaban locos (Miguel, 2010: prólogo).

\footnotetext{
${ }^{30}$ La referencia carece de página porque es un artículo periodístico consultado en formato virtual en el soporte que se indica en la bibliografía.

31 Ídem 
En segundo lugar, el libro colectivo titulado Calle de las impertinencias, que fue autoeditado en 2012 por sus autores y en 2013 sería publicado por la editorial Germanías:
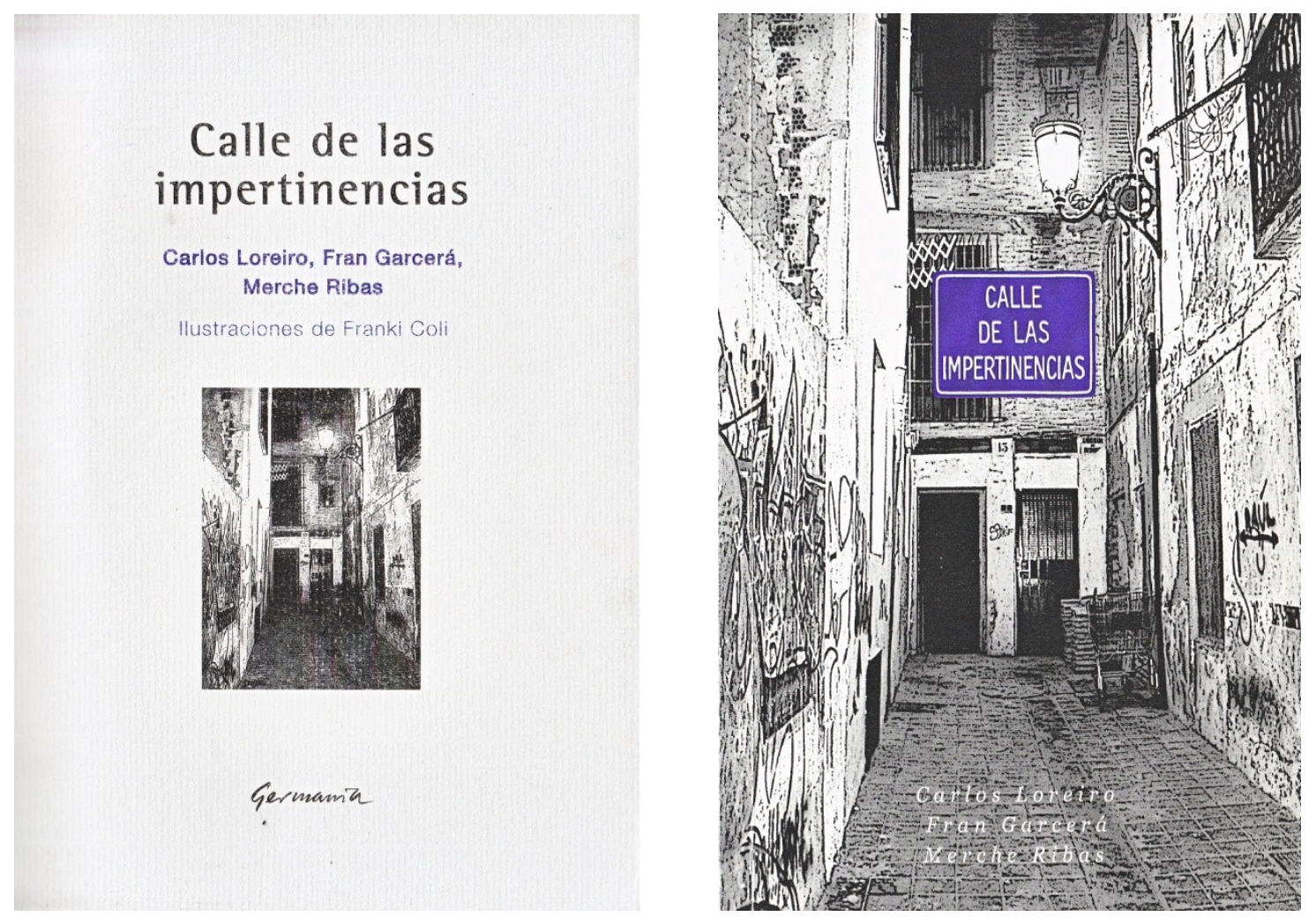

En él se reúnen tres poetas menores de veintisiete años: Carlos Loreiro, Fran Garcerá y Merche Ribas, junto a las ilustraciones de Franki Coli. El libro está dividido en tres partes según las obras de los poetas y van encabezadas por un título propio cada una: "5 contra 1", "El hambre" y "Animálcelo" respectivamente. Mientras que la primera y la última parte dan paso a los poemas tras el título, el apartado de Garcerá abre con dos citas, una correspondiente a Luis Rosales ("Vivimos arrojados al mundo y nuestra piel / se encuentra ardiendo...") y otra correspondiente al libro Credo de Xelo Candel, la prologuista y también poeta ("No te llenes la boca / de sombras, no te calles...").

Este libro colectivo enuncia su propósito ya desde el título inicial: ser impertinente consiste en hablar acerca de la situación de crisis en la que vive el país, poner de relieve los problemas y el desastre que ha originado, a la postre, el sistema capitalista. Se lleva a cabo un recorrido por asuntos actuales como la educación pública, las manifestaciones o la desigualdad, junto a temáticas amorosas y, si se quiere, trascendentales (como en el poema de Fran Garcerá: "Silencio. / ¿Hay alguien ahî́? / (potencia sensitiva del corazón) / a lo lejos un eco y silencio. / Silencio"). El libro se enuncia a sí mismo como un lugar de crítica, de grito y de protesta frente a esa situación impuesta por la racionalidad gubernamental, frente a esa lógica neoliberal donde la dinámica competitiva capitalista ha derivado en una crisis económica que los propios autores conocen y viven en tanto ciudadanos. "La nocturnidad de los bares [...] el amor y sus heridas, los ritos de la seducción o la traición adornan algunos 
poemas en los que se evidencia el vacío ante el que se enfrenta una sociedad que va perdiendo los pilares básicos sobre los que se sustenta" (Candel Vila, 2012, 6-7).

Hay un elemento reseñable en este libro colectivo que nace junto y gracias a los poemas: los grabados o dibujos del autor Franki Coli:

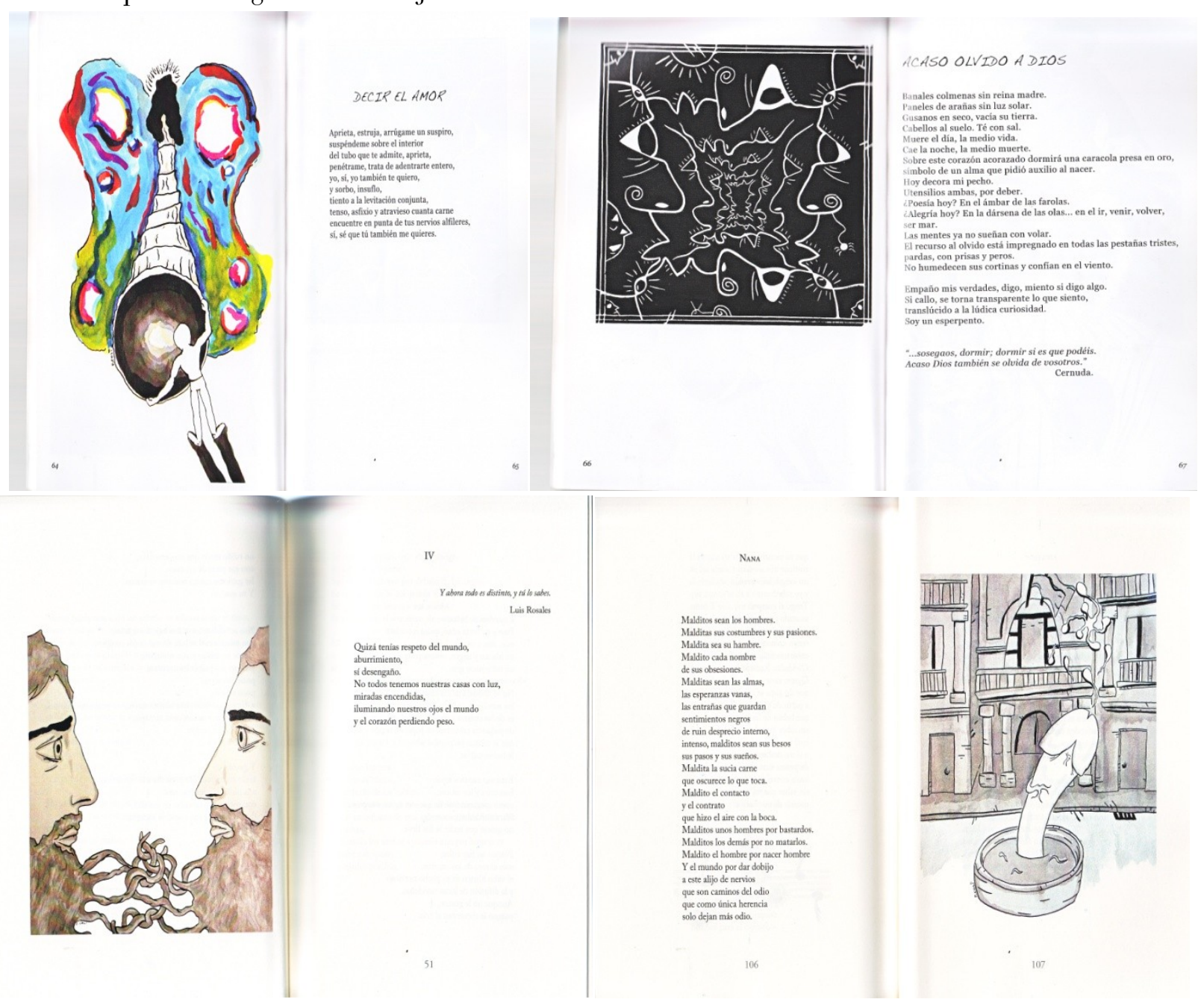

Imágenes realizadas por Franki Coli para Calle de las impertinencias

Decía Nuria Girona a propósito de la obra de Girondo:

Estos bocetos esquemáticos definen las características iconográficas de la poesía, reforzadas con las ilustraciones que la acompañaron en la edición original. El uso del código verbal y visual a partir de los mismos semas manifiesta esta función referencial, pues el dibujo funciona como un duplicado de las imágenes poéticas, que a su vez remiten a un referente externo (Girona, 1996: 225).

De igual modo, los dibujos de Coli son imágenes monocromáticas y policromáticas que representan visualmente el contenido poemático y que, tras la primera edición (donde se limitaban al apartado de Merche Ribas), se extendieron a todo el libro. Podría decirse que, en tanto duplicado del poema, también las imágenes son duplicados de la rabia, el desencanto o la fuerza que en ellos se traduce. 
Calle de las impertinencias es, como dice su prologuista, "una palabra desencantada [...] una mirada corrosiva sobre el mundo" que ha reunido bajo el mismo libro a poetas de signo diferente, sin importar la extensión de sus versos, el matiz de sus rimas o los temas que recorran sus poemas; una palabra desencantada que pretende ser impertinente ${ }^{32}$.

En tercer lugar, se analizará el poemario anónimo titulado El bate de béisbol de Michael Douglas. Este poemario, publicado en 2014, aparece exclusivamente en soporte virtual, acompañado de gifs ${ }^{33}$ cuyo contenido traduce una idea de rabia o violencia siempre marcada por la ironía (una serpiente mordiendo a un hombre disfrazado de conejo, un hombre en llamas saludando a otro al salir de la oficina, el golpe en la nariz durante un combate de boxeo, etc.):

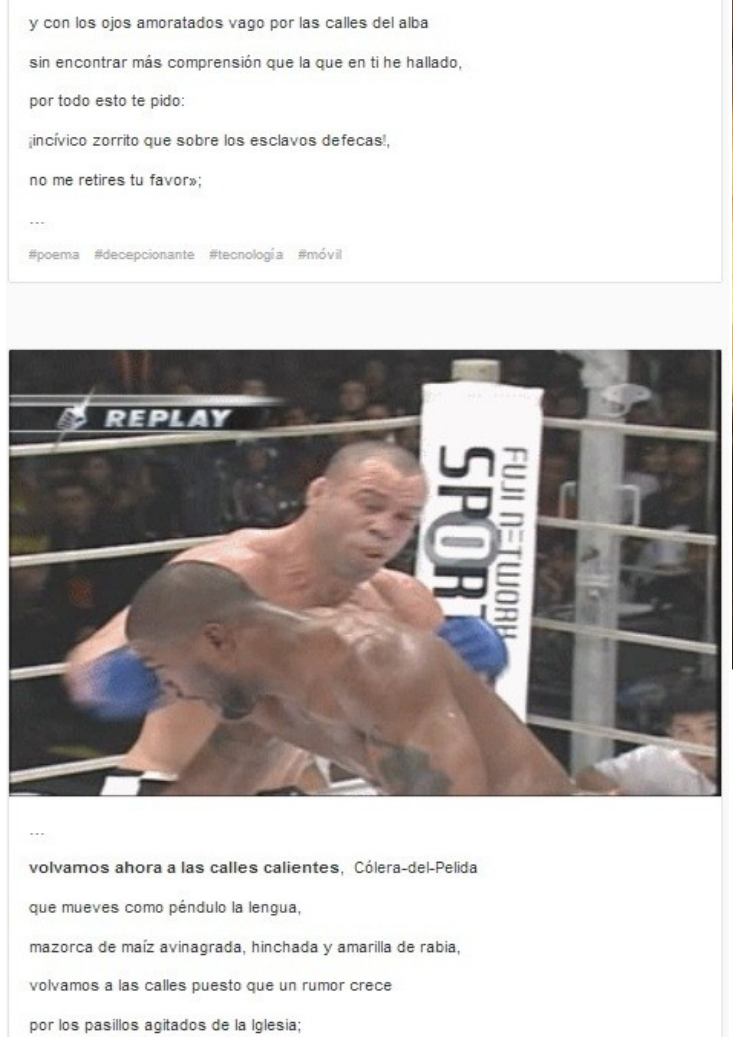

Imágenes que encabezan los poemas en El bate de béisbol de Michael Douglas

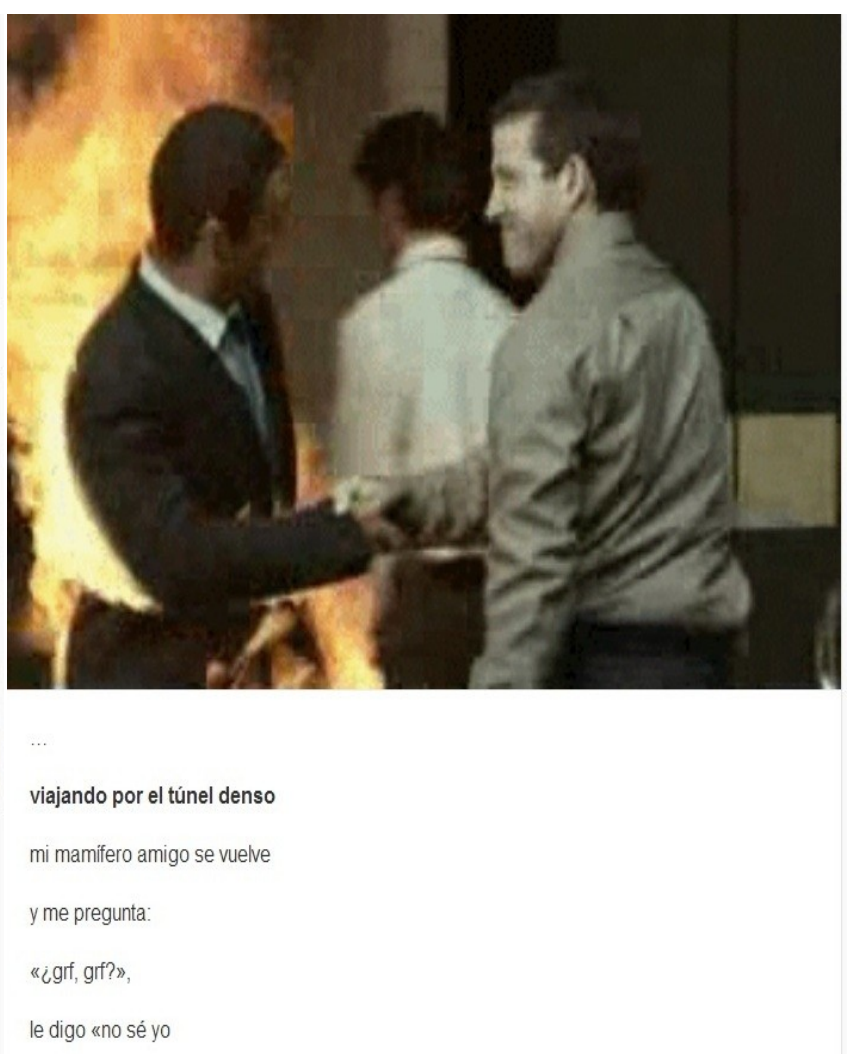

migo se vuelve

me pregunta:

digo «no sé yo

\footnotetext{
32 "Recogemos en este libro las voces de tres jóvenes poetas que se sitúan en esta línea poética de un realismo de protesta que critica, desde la indignación, no ya solo los abusos del sistema capitalista, como habían hecho otros poetas realistas en años anteriores, sino la incapacidad del propio sistema para seguir adelante, para llevar a cabo políticas de integración y de igualdad social. Desde una palabra desencantada se denuncia la injusticia social, las desigualdades en la era del neoliberalismo, las políticas antisociales del gobierno, la dominación del sujeto por el sistema en el fin de la 'era del bienestar'. Son jóvenes que viven un momento de crisis económica y no renuncian a dejar constancia de su indignación ante una política que les deja sin perspectivas laborales y que ataca sus libertades más elementales"(Candel, 2012: 5-6).

${ }^{33}$ GIF (Compuserve GIF) es un formato gráfico utilizado ampliamente en la World Wide Web, tanto para imágenes como para animaciones. Un gif es una imagen en movimiento repetido.
} 
Uno de los elementos reseñables de este poemario online es precisamente su título, que nace a partir de la película Un día de furia: el film narra las diferentes formas de violencia que lleva a cabo el protagonista, William Foster (Michael Douglas) durante el día del cumpleaños de su hija. La rabia es un elemento vertebrador de la actitud del protagonista y es, también, un elemento vertebrador en el poemario. El bate de béisbol de Michael Douglas es, a grandes rasgos, una forma de reaccionar ante ese estado de shock bajo el que se escribe: "ahora mecagoendiós solamente pero mi fuerza es sobrehumana". El filósofo Byung-Chul Han habla sobre el sentimiento de la rabia en su obra La sociedad del cansancio de la siguiente manera: "La rabia es una facultad capaz de interrumpir un estado y posibilitar que comience uno nuevo" (2012: 56). El poemario se instala precisamente en ese tránsito violento: es la expresión de la rabia ante el estado de las cosas que anuncia la posibilidad de un cambio, pero sin llegar a definir su naturaleza ni su dirección.

El segundo elemento reseñable del poemario es precisamente su autoría anónima y la utilización (tal y como ocurría con la obra de Luna Miguel) de los soportes digitales para difundir la poesía. En apartados anteriores se ha explicado cómo Internet genera, en muchas ocasiones, espacios de producción poética al margen de las exigencias del sistema editorial y eso es precisamente lo que supone esta obra. El soporte virtual facilita, además, no solo la huida de las exigencias editoriales, sino también la huida de las exigencias que genera la propia noción de autoría: aquí la poesía no es una herramienta de obtención de capital económico ni cultural. En este poemario anónimo el sujeto se diluye y representa, a la postre, la voz abstracta de la rabia que ha provocado el sistema neoliberal con la emergencia de una crisis como la española.

\subsection{La voz traumatizada: hacia una teoría del sujeto en estado de shock en la poesía} española

Todo lo planteado en apartados anteriores sobre los efectos en la subjetividad de la crisis neoliberal en España se traduce en el ámbito poético en la creación de voces específicas que llevan las huellas de ese estado de shock. La problemática neoliberal se inscribe en el discurso de los tres poemarios a través de la construcción de voces muy diversas donde "el sujeto construye el mundo como objeto y se construye a sí mismo" (Laura Scarano, 1994: 13). Lo que sucede, por tanto, con la escritura poética del shock es que reconoce a los sujetos en tanto sujetos traumados a través de las voces que construyen: "Malditos sean los hombres. / Malditas sus costumbres y sus pasiones. / Maldita sea su hambre" (Ribas en VV. AA., 2012: 106).

Laura Scarano traza en su obra una historia de las transformaciones del sujeto poético desde la posguerra hasta los años 70 poniendo en relación las características de la voz poética con el contexto social y político en el que surge, partiendo de la idea de que "en cuanto a la figura del sujeto es posible verificar una modificación sustancial de las alternativas de construcción de la voz escritural" (1994: 23). Así, señala cómo en la primera etapa de posguerra predominó un "yo automagnificado" que ejercía el monopolio exclusivo de la voz textual, pero que fue "desplazado por un sujeto en proceso de dispersión, disociación en otros y colectivización" (1994: 24) hasta dar lugar en los años 70 
a una "alucinada vorágine en la que se pierde el sujeto de esta escritura" (1994: 25). Refiriéndose a la poesía de los años 70, Scarano enuncia una afirmación que podría aplicarse a las poéticas del shock:

El discurso de la subjetividad construido en la poesía (...) pone en escena este desplazamiento dialógico, la fuga hacia los márgenes de voces dispersas que volatilizan aquel sujeto unívoco y centrado de la tradición lírica moderna, acentuando sus máscaras e imposturas, sus silencios y sus fragmentaciones (1994: 27).

Esta crisis del sujeto unívoco se incrementa, según Joan Oleza y José Luis Ángeles, con la llegada de la posmodernidad que genera la dispersión de la conciencia. Esta dispersión se ve fomentada, sobre todo, por la especialización que sufre el sujeto neoliberal y que centra su atención en ámbitos concretos, dando lugar así a una visión fragmentada de la realidad y a una conciencia dispersa:

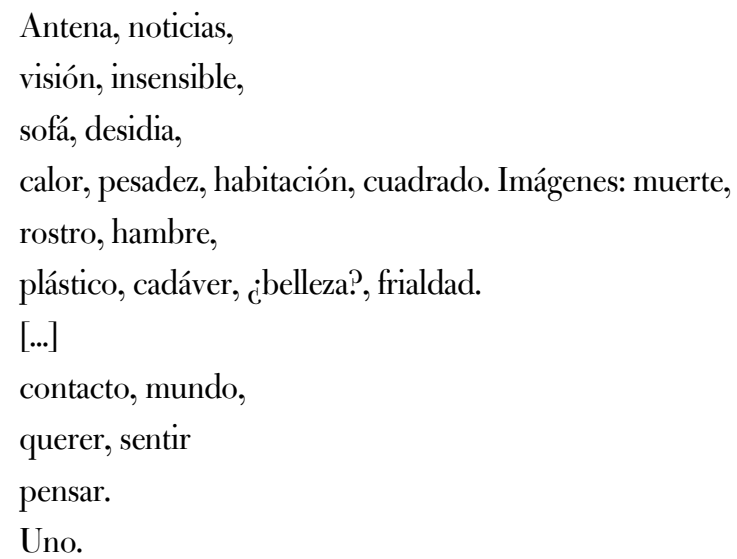

(Ribas en VV. AA., 2012, 86-87).

La disolución del sujeto en múltiples voces permite no solo la incorporación de otros discursos y códigos en el poema, sino también la incorporación del lector al plano poético. La poesía, entendida en tanto estructura polifónica, abre un espacio de interrogación al lector: "sin proponer respuestas (falsamente) totalizadoras sino permitiéndonos que en el juego incesante de su semiosis incorporemos nuestras inquisitivas lecturas, siempre tan precarias como provisionales" (Scarano, 1994: 28).

Las voces poéticas de los tres poemarios representan a sujetos cuya dispersión de la conciencia podemos relacionar con el trauma social del neoliberalismo, pero de maneras muy diferentes. Será necesario centrar el análisis en torno a elementos fundamentales como el lenguaje o la temática para caracterizar a las poéticas del shock. 


\subsection{Tenían veinte años y estaban locos}

Este libro colectivo está compuesto por veintisiete poetas menores de veintisiete años gracias a la labor (primero virtual y después analógica) de Luna Miguel. Al unir en un mismo libro veintisiete producciones poéticas diferentes, lo que sucede es que se apela directamente a la sensibilidad de los lectores desde un efecto de locura poemática. La locura (diagnosticada en tanto enfermedad por la psiquiatría) se identifica precisamente con esos cambios o trastornos aleatorios de la conciencia y este esquema es el que presenta el libro: un poema que dibuja imágenes sangrientas ("Regreso con sangre entre las piernas / golpea, gotea, chorrea / sangre derramada" Marina Ramón- Borja en Miguel, 2011: 127) da paso a una composición de cinco versos sobre las equivocaciones ("Equivocarse es / utilizar una cuchilla de afeitar / para lavarse los dientes" Cristina Fernández en Miguel, 2011: 52), que a su vez anticipa otra composición más extensa hablando sobre el paso del tiempo ("Dejar caer la vida / rogarle que no duela" Laura Rosal en Miguel, 2011: 151) y así sucesivamente.

Lo enuncia Luna Miguel en el prólogo (2011): "Los había, sí, que volaban: Laura Casielles, María Salvador... Los había, en este libro, que sabían construir: Ruth Llana... Y los había (en este libro, sí, sí, en este manicomio joven, lúcido y lírico) que nunca rezaban: Berta García Faet..." (Luna Miguel, 2011: 9-19). Habla precisamente de un manicomio al que le adjudica tres rasgos fundamentales: la juventud de sus pacientes, el carácter lúcido y el lirismo. En la obra de David Cooper se hace referencia al poeta como aquel ser que, junto al loco, se encarga de transgredir las normas impuestas en el lenguaje que invisibilizan los peligros de la sociedad. "El 'lenguaje de la locura' significa la forma de expresión de esta locura universal, no solo mediante la emisión de palabras audibles sino en un tipo de acción, a través de la experiencia, que es el "discurso demente"“" (David Cooper, 1979: 18).

Esta alusión a la locura que da título a la obra es un síntoma significativo precisamente de las circunstancias socio-históricas: la locura se entiende en tanto lugar de resistencia a los procesos de homogeneización subjetiva, es decir, podría erigirse como una representación de aquello que se resiste a los procesos de normalización de la modernidad avanzada y, por tanto, quizás así pueda entenderse la locura como una metáfora de las subjetividades díscolas que no encajan en la idea de sujeto neoliberal desarrollada por Laval y Dardot.

Ahora bien, como se ha indicado en el apartado anterior, este título procede de un poema de Bolaño y del mismo modo que resulta reseñable el concepto de locura, también lo son los versos del autor chileno: "En aquel tiempo yo tenía veinte años / Y estaba loco. / Había perdido un país". Es precisamente esa pérdida de país uno de los sentimientos generalizados que surgen a raíz de la crisis española: la privatización de los servicios públicos hace que los ciudadanos sientan una pérdida de los derechos de asistencia básicos que, a su vez, se suman a las cifras ascendentes de emigración entre la juventud. Es por eso que estas nuevas subjetividades utilizan la locura no en tanto enfermada psiquiátrica, sino como un elemento de resistencia frente a la pérdida.

Uno de los elementos donde cristaliza todo ello es en la utilización del lenguaje, que en este manicomio lírico adquiere formas muy diversas: por un lado, hay composiciones 
que mezclan idiomas intercalando el uso del francés y el castellano en versos sucesivos, dando forma así a otro modo de poema polifónico ("Je ne sui spas une femme / yo no estoy enferma / Je suis désolé" Eba Reiro en Miguel, 2011: 133). La voz poética juega con las similitudes fonéticas de las palabras e inventa una realidad a partir de dos idiomas diferentes; lo que sucede, por tanto, es que la voz va buscando diferentes idiomas en los que acomodarse y desde los que hablar. Por otro lado, hay composiciones que reformulan tópicos de la literatura para establecer monólogos interiores ("Apuesto conmigo misma: «si muerde, me quedo» /. Y el perro del hortelano ladra, ladra, ladra” Laura Casielles en Miguel, 2011: 37): la tradición se redefine, en este caso el perro del hortelano sirve como tópico en el poema para focalizar un diálogo de la voz consigo misma en el momento de tomar una decisión, pero lo mismo sucede con otros elementos del arte o la cultura, como las catedrales: "era una catedral del siglo XIII / solo nervios y vanos, / y nada alrededor, clara y oscura" (María M. Bautista en Miguel, 2011: 99). La utilización de símbolos pertenecientes a la cultura (perro del hortelano y catedral) se trasladan hasta la realidad sentimental del sujeto que habla (intimismo) y genera, así, un choque en el lector que interpela su sensibilidad de forma diferente. Este recurso manifiesta de manera implícita la forma en que el shock político ha interpelado previamente la sensibilidad del autor, lo realmente importante no es la simbología sino la realidad inmediata, ya sea esta política o amorosa.

En este manicomio de poetas lúcidos hay también voces que conceden al poema el espacio de un solo verso "TENGO UN HOLOCAUSTO en cada sien que me late" (Judit del Río en Miguel, 2011: 139), generando así un espacio donde la inmediatez y la exactitud de la palabra define toda la composición. Podría decirse que son poemas al más puro estilo de los eslóganes publicitarios que copan las aceras, cada vez más, de las ciudades que nacen al amparo de la modernidad avanzada. Por otro lado, también hay voces que interrogan a través de la prosa poética “ ¿Y por qué creer en todo esto? ¿por qué no / desfilar desnudo, en la línea infinita que separa / la broma del llanto?" (María Salvador en Miguel, 2011: 163). La voz no teme preguntar de manera directa, interpelar las sensibilidades y remover las conciencias a través de sus dudas. Y hay, también, una gran mayoría de voces que experimentan de manera directa con la forma del lenguaje; de modo que los espacios en blanco, el uso de mayúsculas o las palabras inventadas y combinadas redefinen el shock estético que ya defendió la poesía en clave vanguardista.

Žižek, como se ha señalado anteriormente, habló acerca de la doble concepción del lenguaje: por un lado como elemento liberador que permite la configuración del pensamiento, pero por otro lado como elemento opresor que cristaliza las subjetividades y es utilizado por las instituciones de dominación. "De-encima-de-oreja- a encima-de-oreja: / un tiro porque me toca" (Judit del Río en Miguel, 2011: 139), "hablábamos, / hablablablablablablá" (David Leo García en Miguel, 2011: 58), "d / e / d / o / s" (Cristian Alcaraz en Miguel, 2011: 28):

\footnotetext{
En sombras de esto
} 
y quizá también

de aquello

(Enrique Morales en Miguel, 2011: 112).

Esta experimentación con el lenguaje también tiene que ver con la locura: "La locura es un movimiento que sale del familiarismo y va hacia la autonomía. Este es el verdadero peligro de la locura y la razón de su violenta represión" (David Cooper, 1979: 21). Este movimiento de autonomía es el que realiza el libro colectivo de Luna Miguel "porque en este tiempo difícil para la juventud, minado por el desconcierto y la indignación, sólo la Literatura y Su Literatura pudo traer un poco de esperanza. Eran poetas. Eran hermosos. Estaban locos" (Luna Miguel, 2011).

\subsection{Calle de las impertinencias}

Este libro colectivo cuenta con una estructura tripartita, explicada en el apartado anterior, que distingue y al mismo tiempo recoge tres voces poéticas diferentes. La obra es entendida como un lugar de encuentro donde la emergencia de nuevas subjetividades díscolas, que reaccionan ante el estado de shock neoliberal, actúa como factor aglutinador. En este libro colectivo la palabra se erige como el instrumento que verbaliza y testimonia una realidad actual donde el amor, las manifestaciones y la increpación continua, ya sea personal o colectiva, se entremezclan: "Me levanto, animo a mi padre a que soporte / un día más y paseo solo hasta la plaza llena de pancartas / y de gente jaleando horrorizada" (Loreiro en VV. AA., 2012: 17); “ ¿Dónde guardaste, madre, / la tirita electoral? / Búscala deprisa, / que esta herida vuelve a abrirse" (Garcerá en VV. AA., 2012: 50). El lenguaje dibuja cuadros donde se representa una realidad actual que verdaderamente no está hundiéndose, sino reconstruyéndose, pero bajo la doctrina del neoliberalismo y su política de privatizaciones: "de la escuela pública / ya ni rastro" (Garcerá en VV. AA., 2012: 45). El propósito que une a los tres poetas es precisamente la intención de increpar e interrogarse a través del lenguaje sobre el contexto que les envuelve y su forma de desenvolverse en ese medio; no obstante, hay también tres formas diferentes de cristalizar esa intención en el lenguaje. En definitiva, si el estado de shock en España genera efectos en la subjetividad, ¿de qué manera pretenden estos poetas afectar a la sensibilidad del lector, despertarlo o interpelarlo?

Por un lado, Carlos Loreiro emplea un tono que tiende a la ironía y que, por ello, le permite en muchas ocasiones conjugar registros diferentes, no solo entre poemas, sino dentro de una misma composición: "Y ni fue nunca ese el tempo de Bach / y ni eso sonó jamás a Schubert pero qué cojones / yo la quería y ella no se iba a dar ni cuenta" (Loreiro en VV. AA., 2012: 32), "Por $100 \mathrm{Kc}(4 €)$ me he chupado la temporada entera / de ópera con hincapié en Mozart y Puccini" (2012: 33), "No tuvo Villon más cojones que ella, ni Rimbaud / ni Kerouac ni Pasolini ni todos los sementales juntos" (Loreiro en VV. AA., 2012: 21). La ópera y la literatura, Mozart, Puccini, Beethoven, Kafka o Bach se mezclan en composiciones poéticas heterogéneas para terminar hablando del amor o del yo lírico: "Frente a la tumba del viejo Franz vuelvo / a sentirme un criminal infame" (Loreiro en VV. AA., 2012: 33). Loreiro crea, por tanto, voces poéticas que sugieren al lector referentes 
culturales (compartidos o no) y que sirven, en última instancia, como escenarios para hablar de temáticas comunes. El yo lírico se presenta a menudo como un ente con referentes culturales abundantes, pero que no le sirven para elevar o alejar su poesía, sino por el contrario, para mezclar todos los registros que domina: el sexo y la ópera están al mismo nivel y eso es algo que se identifica con la conciencia dispersa de la modernidad avanzada, tratada anteriormente, y que fomenta el carácter polifónico de la poesía.

La ironía del poeta reside no solo en esta licencia para mezclar registros, sino también en la utilización del lenguaje para desmontar su propia obra: "No es sensato que lo que unos le quiten al mundo / otros quieran devolvérselo con palabras" (Loreiro en VV. AA., 2012: 15), "No es interesante un libro, ni lo será nunca y eso / uno lo empieza a comprender más tarde" (Loreiro en VV. AA., 2012: 23). El lenguaje empleado como una herramienta para desacralizar el propio lenguaje poético y el reconocimiento de los límites de la palabra subyace en algunos versos y confieren a su obra un carácter no solo irónico sino también escéptico y paradójico, ya que critica el mismo medio que utiliza para intervenir en su realidad histórica: "La desconfianza, el escepticismo, la incredulidad ante la realidad social, la incertidumbre, el temor e incluso cierta apatía no eluden su responsabilidad ética y social sino que la ponen de relieve" (Candel, 2012: 7).

Ahora bien, dentro de esa concepción irónica y desconfiada del lenguaje, Carlos Loreiro emplea una serie de procedimientos para ordenar el discurso de las voces poéticas. La mayoría de sus poemas constan de versos largos, que desprenden la sensación en ocasiones del horror vacui o miedo al vacío, y algunos poemas de versos más reducidos (como «Erbarme dich»), donde lleva a cabo un constante empleo del encabalgamiento: "Qué ambiente el de ahí fuera. Está / la plaza abarrotada" (Loreiro en VV. AA., 2012: 25), "eran dos metrónomos / enloquecidos" (Loreiro en VV. AA., 2012: 28). En todos ellos, aunque el discurso se organice de formas diferentes, el sujeto traduce a elementos poéticos la carga sensorial y física, el ritmo frenético, cargante o atropellado de la vida en la modernidad avanzada donde la inmediatez traspasa hasta las relaciones amorosas, tal y como dec34ía años atrás José Martí "se ama de pie en las calles", Carlos Loreiro escribe: "Me gusta Lola, es cierto, no me es posible / negarlo. Qué me importa si su piel no es tan suave / como la de las demás, las anteriores" (Loreiro en VV. AA., 2012: 21) ) $^{35}$.

34 En el debate contemporáneo se utiliza para definir nuestro estado sociocultural diferentes categorías que provienen de diferentes tradiciones de pensamiento. Se habla de posmodernidad, sobremodernidad, hipermodernidad, ultramodernidad, modernidad líquida. Como ese debate excede con mucho los objetivos de este artículo y sin negar el interés de las categorías precedentes, utilizaremos el término de modernidad avanzada para referirnos al momento actual en que escriben estos poetas.

35 Esta influencia del contexto socio-histórico que rodea al poeta y su traspaso al poemario fueron tratados por el propio Carlos Loreiro en una entrevista realizada para el presente trabajo: "Las circunstancias por las que corre la suerte de uno mismo me parecen el motivo fundamental por el que escribir, y no solo sobre el que escribir. Es decir, si acaso el contexto histórico me quedaría muy grande (actualmente y por motivos extrapersonales, ni estudio ni trabajo, así que no se me podría considerar un ente social o político, o como quiera llamarse) son exclusivamente las vicisitudes personales las que me mueven a escribir" (2014). Es decir, las circunstancias que rodean al poeta lo moldean y le influyen en tanto ciudadano y eso se traduce en sus poemas partiendo de 
Por otro lado, el lenguaje de Fran Garcerá da forma a una "voz crítica", como señala Xelo Candel en el prólogo, con un registro sin excesivas variaciones ni contrastes, con una voz que hace suya y que mantiene un tono crítico, increpador y cuestionador: " ${ }_{\mathrm{C}} \mathrm{Y}$ la grieta?, / nos preguntamos unos a otros / mirándonos los pies" (Garcerá en VV. AA., 2012: 47), “¿Por qué nos engañasteis? / ¿Por qué nos dejamos engañar? / ¿Por qué?” (Garcerá en VV. AA., 2012: 53). Es un lenguaje que testimonia el contexto y lo valora: "si hubiese sido 8-M y no 15-M, / la policía se habría quedado en casa comiendo, y los jueces, / y los otros" (Garcerá en VV. AA., 2012: 37). En medio de las revueltas sociales, del hambre y el cierre de la escuela pública, también la voz increpa cuando se habla de amor: "Nunca nos dijeron que el amor fuera esto [...] pero hay un problema entre nosotros, / dicen, / nuestra barba la una contra la otra" (Garcerá en VV. AA., 2012: 39). El propio poeta afirmaba: “en mi caso, no creo que rompa ni continúe con la tradición, solo me encuentro en la búsqueda por una palabra exacta que dé cuenta de mis heridas e inquietudes" (2014, entrevista).

Uno de los elementos más reseñables en las voces críticas que se conforman en la obra de Fran Garcerá es que, en muchas ocasiones, interpelan la sensibilidad del lector a través del uso de una simbología poética tradicional que consigue desplazar hacia el contexto político actual y generar así una ruptura de expectativas: "Víctimas, / de cuando los sueños se cambiaron por hipotecas" (Garcerá en VV. AA., 2012: 42): la idea del sueño como concepto abstracto, recurrente en el universo poético, y la idea de las hipotecas en tanto concepto concreto perteneciente a la realidad actual que endeuda a los sujetos.

\author{
Ahora marchad, \\ soldaditos de plomo, \\ todos de azul, \\ todos uniformados, \\ la escuela os espera. \\ Sois el futuro. \\ Vuestros padres bien lo pagan \\ (Garcerá en VV. AA., 2012: 45).
}

De nuevo, la utilización de un símbolo (el soldadito de plomo) recurrente en el universo literario se traslada hasta los sujetos concretos de la modernidad avanzada: los niños que estudian en la escuela privada y que, como soldaditos, comienzan a obedecer las leyes del sistema capitalista y privatizador. No obstante, el poeta no solo utiliza elementos de la simbología poética o literaria, sino también frases o expresiones propias del imaginario común:

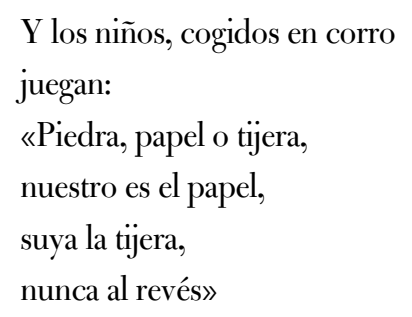

circunstancias personales concretas con las que construye voces que interpelan la sensibilidad del lector. 
(Garcerá en VV. AA., 2012: 49).

La ruptura de expectativas se produce al combinar un juego popular (piedra, papel o tijera: sinónimo de inocencia) y una realidad provocada por la violencia neoliberal (la reducción de ayudas en los servicios públicos). La voz crítica desplaza el papel y lo convierte en el elemento del que el poeta debe valerse para responder a esa reducción de ayudas, y a su vez convierte la tijera en un elemento metonímico para representar las políticas privatizadoras. Este recurso de desplazamiento entre la simbología popular y los símbolos de la violencia capitalista genera un choque en el lector e interpela a su sensibilidad de forma agresiva, manifestando así la forma en que el shock del neoliberalismo ha interpelado previamente la sensibilidad del poeta.

El yo lírico, del mismo modo que sucedía en varios poemas de Carlos Loreiro, se cuestiona también sobre la función del lenguaje en mitad de ese "mundo convulsionado y atroz" para conceder a la palabra el deber de testimoniar lo que sucede, "hay que escribirlo todo":

\author{
El hambre pisándonos los talones -decías-; \\ el desprecio hacia el hombre y hacia la libertad humana. \\ Hay que vivir contra todo y a pesar de todo \\ en un mundo convulsionado y atroz. \\ Vivir viéndolo todo y sufriéndolo todo con todos. \\ Terminó la íntima soledad del poeta. \\ Porque también hay que escribirlo todo
}

(Garcerá en VV. AA., 2012: 44).

En estos versos subyace un ideario poético sobre la función del escritor en ese contexto que comienza a erigirse sobre privatizaciones y desmantelamientos de los servicios públicos. El poeta, según Fran Garcerá, tiene "que escribirlo todo" y esto no es una idea nueva, pero sí redefinida: en la poesía social de los cincuenta el poeta también tenía que dar cuenta de las injusticias sociales y bajar a la tierra con el resto de los hombres, tal y como decía Blas de Otero, pero en este caso la labor es mucho más compleja: no se trata de defender a los hijos de la guerra, sino de testimoniar el peligro que existe bajo esa forma de sistema democrático, donde los estados de shock que se provocan pueden llegar a conformar un tipo de violencia aún más peligrosa ${ }^{36}$. A propósito de esto, Žižek habla de la violencia sistémica como "la consecuencia a menudo catastrófica del funcionamiento homogéneo de nuestros sistemas económico y político" (2009: 10).

Por último, el lenguaje de Merche Ribas, "cuyo denominador común es el desencanto ante la realidad, la mirada corrosiva sobre el mundo, el descreimiento en la

\footnotetext{
${ }^{36}$ Fran Garcerá: "Pero si otra cosa debe hacer la poesía, o el poeta, es erigirse como testimonio de la memoria. Decirlo todo. Nombrarlo todo. Preguntarse todo. Hay una percepción distinta en la poesía, más inmediata y primigenia, que no alcanza a la novela o a los otros géneros (lo mismo ocurre al contrario en otros aspectos), que debe ser aprovechada para dar buena cuenta a las próximas generaciones de lo convulso, atroz y falso que tienen nuestros días, para contraponer una historia distinta, más humana y cierta, a la que se establece como la historia oficial de nuestros siglos" (2014, entrevista).
} 
palabra y su capacidad para transformar la realidad. La suya es una voz descarnada, sin alardes retóricos [...] que abarca la realidad desde un expresionismo tremendista" (Candel, 2012: 9). Merche Ribas emplea un juego de estilos poéticos, similar al juego de registros que llevaba a cabo Carlos Loreiro, y utiliza la retórica de la metafórica irracionalista ${ }^{37}$ de la poesía del siglo XX que traspasa hasta llegar a la crudeza de un realismo visceral, expresado en un léxico y en un lenguaje cuya materia de base es la lengua común:

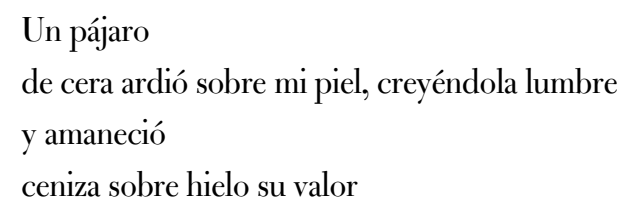

(Ribas en VV. AA., 2012: 59)

Podría decirse que las voces poéticas de este poemario son las más diferentes entre sí dentro de todo el libro colectivo. Hay una dispersión total de la conciencia del sujeto ${ }^{38}$, que interpela a los lectores desde tonos y estructuras muy diversos: la voz interrogante y violenta ("¿Quién te dio el poder, quién? / si la calle no es tuya ni es mía" Ribas en VV. AA., 2012: 78, "Les faltan pañales / con tantas ideas" Ribas en VV. AA., 2012: 93), la voz que testimonia ("Han muerto los pies descalzos / y la sal hispana / en la herida de América" Ribas en VV. AA., 2012: 75), la voz fragmentada que se dispersa en el funcionamiento del sistema ("Antena, noticias / visión, distancia, / veloz, insensible" Ribas en VV. AA., 2012: 71) o la voz que ama rimando ("Taconeo en el tablado / del techo de tu recuerdo / y se remueven los temblores / de mi falda en tus cimientos" Ribas en VV. AA., 2012: 69). En muchas de estas voces que van presentándose a lo largo del poemario hay un factor común en ellas y es precisamente el tono musical ${ }^{39}$ :

\footnotetext{
37 Según Carlos Bousoño, en su obra El irracionalismo poético, la utilización de la metáfora irracional surge a partir de la modernidad y consiste en la unión de dos elementos que no tienen ninguna relación analógica - como sucede en el poema de Merche Ribas: el pájaro y la cera- (Carlos Bousoño, 1981).

38 "El contexto histórico atraviesa mi persona, mi lenguaje. A nivel temático, por ejemplo, creo que no podría tratar la sexualidad como lo hago si no hubiera habido una batalla campal para frenar el patriarcado durante tantos años por parte de la resistencia feminista [...] Por otro lado, estamos en el gran momento de destapar la gran estafa que es la estructura política del estado, de linaje claramente franquista. La denuncia forma parte del idioma, cómo nombramos la realidad, qué significa "democracia". Si hablamos de otra manera, ya estamos viviendo de otra manera (acción), sin esperar a que tenga que derrumbarse todo desde arriba" (Merche Ribas: 2014, entrevista).

${ }^{39}$ La propia autora afirma en la entrevista: "He oído alguna vez 'no entiendo nada de lo que escribes' y me importa que los conceptos lleguen. A esto sigo dándole vueltas. Creo que este es un punto fundamental que me hizo pasarme a la música. Ya no dicen no te entiendo, sino estoy de acuerdo o no lo estoy. $\mathrm{O}$ no lo estoy pero me has emocionado, con lo cual hay intento de entender. Y al mismo tiempo la rabia tiene más espacio" (Merche Ribas: 2014, entrevista).
} 


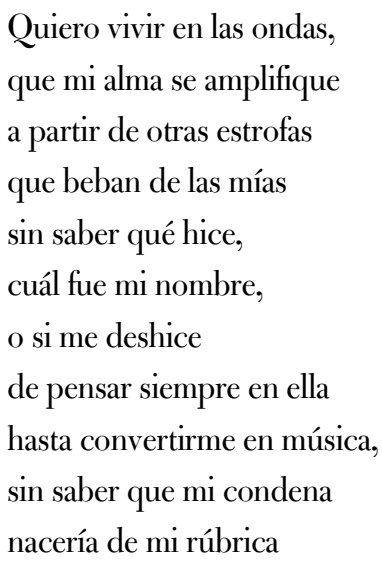

(Ribas en VV. AA., 2012: 90).

Su concepción de la palabra poética no desemboca en la ironía de Carlos Loreiro, ni en la fe de Fran Garcerá, sino que confiere al lenguaje la categoría de instrumento insuficiente para cambiar el mundo, pero destacando que esa insuficiencia es responsabilidad del mundo y no del propio lenguaje. La autora afirma: "Me han dicho que en mi parte del libro ven mucho pesimismo. Aquí es donde haber escrito desde la rabia y punto me puede parecer un problema" (2014, entrevista). La entrevista ha sido realizada dos años después de la publicación del libro y, en palabras de Merche Ribas, lo que pretendía no era hacer llegar un mensaje de pesimismo, sino de rabia, de rabia ante un sistema que no deja espacio para la poesía. El problema que se plantea es, por tanto, que quizá la rabia pueda llegar a interpretarse como una manera de impotencia y de ahí desemboque en el pesimismo o desencanto corrosivo del que hablaba su prologuista: la frustración ante el mínimo poder de la palabra poética frente al capitalismo, la escasa repercusión de la poesía en el mundo de la globalización: "Sobre el hueco del verso / se levanta el imperio / de Dior y Chanel" (Ribas en VV. AA., 2012: 9).

Esta incapacidad de la palabra poética en un mundo regido por las normas del capitalismo se vive desde la rabia y por ello cierra su libro con los siguientes versos: "Me cago en la poesía / desde que se ahogó el último lector / en el vómito de luz que le provocó un verso"40 (Ribas en VV. AA., 2012: 94). Esto traduce una tendencia que ha ido desarrollándose a lo largo de toda la Modernidad: la constatación de la literatura como proyecto frustrado de liberación. Los poetas vanguardistas, como Vallejo o Huidobro, terminaron recusando la literatura como espacio de liberación posible. Merche Ribas abre de nuevo en este poema ese espacio paradójico: "Me cago en la poesía" a través de un poema, dando lugar así a un espacio y a una voz que, en la expresión de su rabia, se niega a sí misma.

${ }^{40}$ La creación de este poema fue tratada por la propia autora en la entrevista realizada para el siguiente trabajo: "Sí que recuerdo un momento digamos fundacional en mi forma de escribir y es que estaba dentro de una clase de poesía y me parecía todo tan soberanamente elitista y postizo que ahí mismo surgió un poema muy visceral contra lo que desde una ideología rancia se considera la tradición y sobre todo el modo arcaico de transmitirla". 
En conclusión, Calle de las impertinencias es un libro colectivo que nace a partir de unas circunstancias socio-históricas concretas sobre las que se interroga (¿qué podemos hacer nosotros con la poesía? ¿Qué papel cumplimos como poetas en un país en crisis?), y cuyas voces traducen a lo poético subjetividades díscolas o rebeladas que reaccionan ante el estado de shock interpelando la sensibilidad de los lectores con procedimientos (conscientes o inconscientes) como la dispersión de la conciencia -traducida en la multiplicidad de voces-, el vaivén de registros y estilos o el traslado de lo poético a la violencia de la realidad actual. En definitiva, Calle de las impertinencias recoge las voces poéticas de tres sujetos que son víctimas de un choque neoliberal y que reaccionan e interpelan a sus lectores de tres maneras diferentes: escepticismo, crítica y desencanto.

\subsection{El bate de béisbol de Michael Douglas}

Este poemario, como se afirmaba en el apartado anterior, parece una traducción a lo poético de la rabia que la película Un día de furia representa a través del personaje de Michael Douglas. Esa representación de la rabia, provocada por la tensión de las exigencias del sistema capitalista y el estado de shock, se traduce a través de varios elementos poéticos. Por un lado, la mezcla radical de registros siempre acompañada de un tono agudamente irónico:

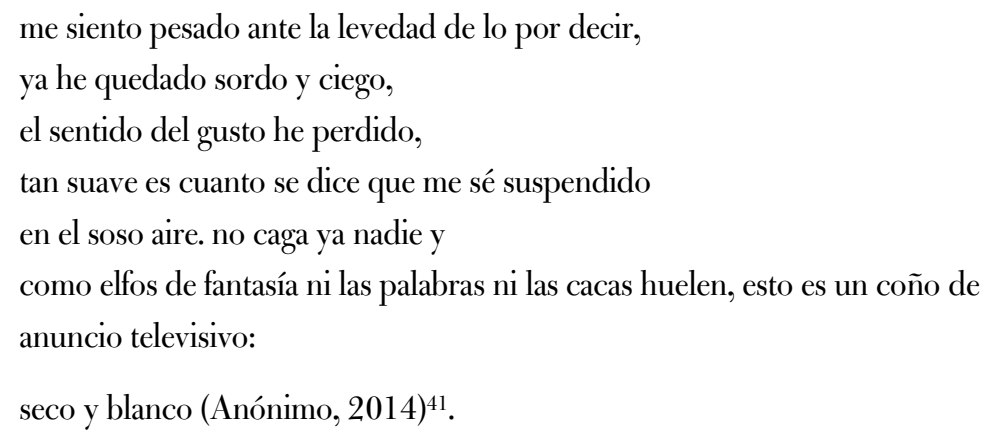

Esa mezcla violenta de registros no se corresponde con la mezcla que se daba en el poemario de Carlos Loreiro o Merche Ribas, sino que se hace extrema y se radicaliza hasta constituir una conciencia dispersa cuya voz va tentando diferentes registros porque no se reconoce en ninguno de ellos. Es un sujeto desprovisto de identidad (esto se fomenta con la falta de autoría del poemario, que no aparece firmado ni con nombre propio ni con seudónimo) y que por tanto va cambiando de posición para ir probando diferentes formas de expresar su rabia. Parece que la propia condición de sujeto en lo único que se reconoce es precisamente en esa falta de identificación con los lenguajes, dentro de cuyo vaivén solo pretende ser: "nada más que el termómetro de una época / fedatario, enunciativo, mecánico, / previsto" (2014). Como afirmaba Nuria Girona al hablar sobre Chantal Maillard: "el mayor malestar no se manifiesta en lo dicho sino en su decir" (2013:3).

Podría decirse, por tanto, que esta búsqueda de registros está directamente relacionada con la vertiente ideológica del lenguaje de la que hablaban autores como Žižek o David Cooper: "Existimos dentro del contexto de un lenguaje que es nuestra propia

${ }^{41}$ Las referencias carecen de página porque son extraídas de una web. 
invención pero que nos controla en la medida en que hemos perdido de vista sus orígenes en nuestra práctica cotidiana" (David Cooper, 1979: 18). Esto fue precisamente lo que plantearon las poéticas en clave vanguardista y lo que de nuevo se redefine en este poemario: si el sujeto no encuentra un registro adecuado para expresar su rabia es precisamente porque la violencia de las instituciones dominantes supone también una violencia sobre el lenguaje que utilizan los sujetos para expresarse.

Por ello, en esta búsqueda de lenguajes es frecuente el uso de un tono violento, marcado por la rabia, que traspasa hasta el léxico: "mecagoendiós, / os quiero tanto a todos pero pienso mataros». Aunque no enuncie de manera explícita su concepción poética, puede decirse que el poema no constituye el lugar de la palabra exacta, sino el lugar donde la duda tiene un espacio ("nada queda para el poeta / salvo el mecagoendiós o si acaso tocar el piano"), donde está permitido mostrar una voz que busca, que se equivoca y que insulta: "tu hermana está triste, no tiene nada que ofrecer, / la muy puta, / ¿en qué lo habrá gastado?, mecagoendiós".

Por otro lado, la ironía acentuada es una muestra de la excentricidad que desprende el funcionamiento de las relaciones sociales en la modernidad avanzada, donde el socialista aventajado matricula a sus hijos en colegios privados ("icívica clase media / que la compostura recomiendas!, ah, ¡socialista avejentado / que a tu prole matriculas en el Liceo Francés!"), las mujeres de la tercera edad se ahorcan por falta de atención ("cuando las señoras heladas reivindiquen la compostura / levitando con ayuda de una soga") y los que prohíben las drogas son los mismos que terminan consumiéndolas ("“cívico policía que la farlopa frecuentas!"). La ironía permite interpelar a la sensibilidad del lector de una forma mordaz, poniendo en evidencia las contradicciones que provoca el sistema capitalista.

Todo ello va acompañado por un elemento visual (los gifs o imágenes en movimiento) que encabezan cada uno de los poemas. Como ocurría en Calle de las impertinencias, las imágenes se constituyen como duplicados de los poemas, pero no necesariamente del contenido, sino del factor sensorial: si el poema se construye a través de la rabia o el horror, la imagen incrementa el sentimiento (boxeadores, caídas dolorosas), si el poema se construye a través de la ironía, la imagen también trata de incrementarla (un ejecutivo en llamas saludando, un animal siendo atropellado). Podría decirse que las imágenes, en tanto cabeceras del poema, anticipan la forma de interpelar a los lectores. EI bate de béisbol de Michael Douglas tiene las características de un poemario que contesta de la forma más radical al shock social que recibe y lo reduplica en un shock estético extremo: 

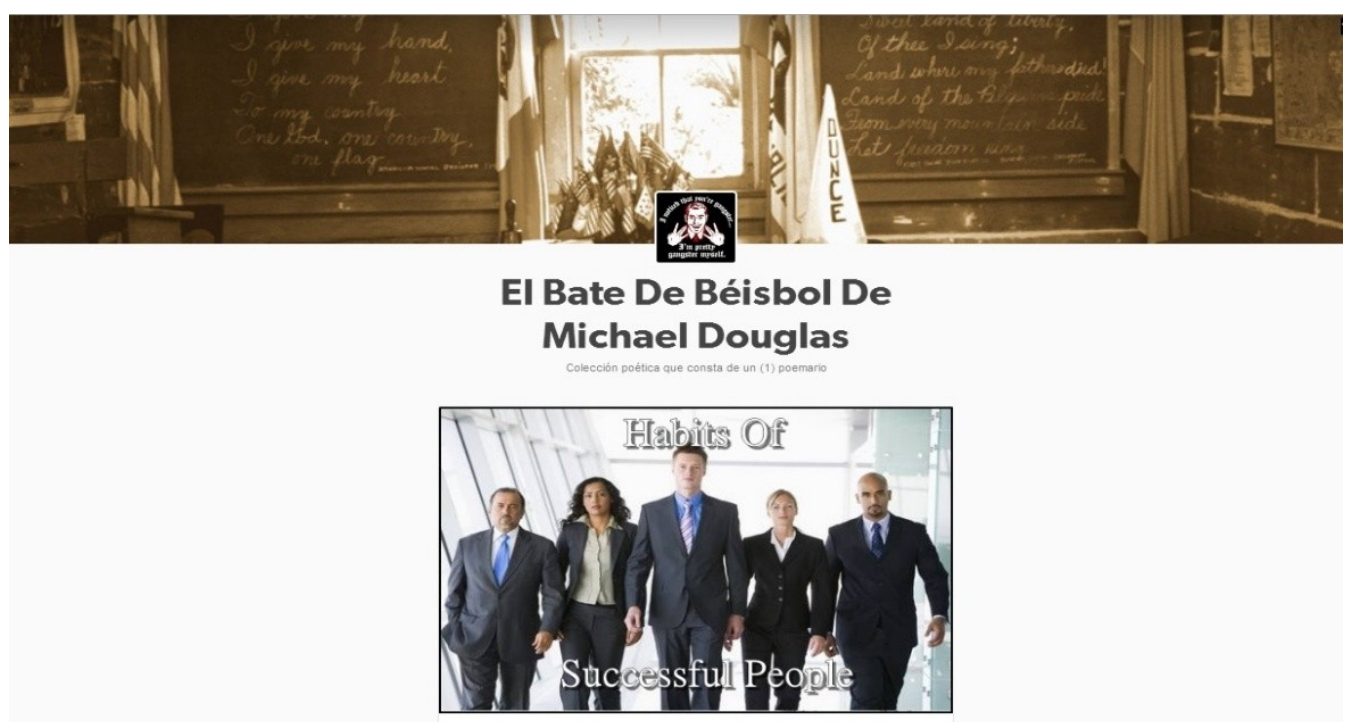

A lo largo de los diferentes poemas hay alusiones vagas a un contexto histórico determinado: manifestaciones ("hay llanto y jaleo - porque una gran manifestación / (donde vehementemente se exigía la no existencia del Rey de España) / ha quedado atrapada en el apocalíptico impasse_-"), cargas policiales ("al salir de la tienda de telefonía / un Policía nos golpea, Nacional, aprovechando la resaca"), y diferentes reivindicaciones sociales ("seguro que seguirá esta danza cuando los gatos domésticos devoren / a los lisiados y cuando los camiones de la basura / recojan las pancartas"). Ahora bien, dentro de esta dispersión del sujeto y la multiplicidad de voces que genera a través de la rabia, hay tres elementos repetidos a lo largo del poemario: por un lado, la apelación a un "zorrito": “zorrito / al que llamo Cólera-del-Pelida"2 tú eres mi único amigo”, por otro lado la frase "mecagoendiós" escrito todo junto y en letra cursiva y, por último, la estructura que repite en cada uno de los poemas con mínimas modificaciones: "os quiero mucho a todos pero pienso mataros", que termina incluyendo a la propia voz: "apreciaba tanto mi vida pero me voy a matar / por no haber sabido captar la trascendencia de las cosas importantes". Esta estructura aparece como un estribillo mecánico de rabia, casi como el susurro de una voz psicótica, alterada hasta el extremo por las circunstancias que le rodean. Lo que configuran, por tanto, los tres elementos, es la imagen de un sujeto cuya recepción del shock político genera una fuerte perturbación que cristaliza a través del lenguaje y las imágenes ("comparte el hombre digno la soledad con el psicópata"). "El loco, al igual que el poeta, rechazaría la propuesta de Wittgenstein de que "el que no pueda hablar debería callarse". Es precisamente lo indecible, lo impronunciable, lo que debe expresarse en el discurso demente y poético" (David Cooper, 1979: 28). De manera que los últimos versos terminan asumiendo esta condición psicótica:

\section{NO QUIERO A MI NOVIA}

\footnotetext{
${ }^{42} \mathrm{El}$ apelativo que esta voz poética concede a su zorrito hace referencia a un elemento mitológico: Peleo fue el padre de Aquiles y por ello este será llamado: Pelida Aquiles. En el Canto I de la Ilíada de Homero aparece la siguiente referencia: "Canta, oh diosa, la cólera del Pelida Aquiles". Referencias cultas se mezclarán con elementos de la cultura popular a lo largo de todo el poemario.
} 


\section{NO QUIERO A TU ABUELA}

quiero ser peligroso

el otro yo

En conclusión, todos estos rasgos poéticos determinan la figura de un sujeto que habla desde el anonimato como una forma de cubrirse el rostro con un pasamontañas (tal y como declaraba el autor en su entrevista) y eludir, así, la autoría monetaria y social. Publicar en Internet un poemario anónimo conlleva una ideología literaria implícita: el poema no debe entenderse como un mecanismo más del engranaje capitalista donde los autores pugnan por la hegemonía, sino una forma de expansión universal que traspase las fronteras sin necesidad de intercambios económicos ni ambiciones orientadas hacia las editoriales más prestigiosas. La elección de Internet es una forma de liberarse de las exigencias del mercado. En la entrevista realizada al autor del poemario, este afirmaba que su poesía es precisamente un nuevo tipo de poesía social para el mundo contemporáneo porque no necesita el amparo de la financiación ni adaptarse a las leyes del mercado, sino sencillamente los medios virtuales que le permitan compartir su escritura. Por ello, en este poemario se crea una voz que puede ser colectiva en su expresión de rabia y el surgimiento de subjetividades díscolas.

Este poemario anónimo, por tanto, se sirve de la utilización de dos shocks: el shock neoliberal como construcción de una voz (confusión, dispersión del sujeto, anonimia) y el shock estético de las vanguardias como modus operandi de esa voz para desautomatizar la conciencia del lector y para redefinir la poesía social contemporánea desde el shock multisensorial (visión de gifs, lectura), que conecta directamente con el poemario de Carlos Loreiro, aunque esta vez de manera radicalizada: el ritmo rápido de los versos se hace extremo para traducir esa hipervelocidad e hiperestimulación de los sentidos de la modernidad avanzada y el neoliberalismo. La poesía, por tanto, traza una línea bidireccional: genera un shock en el lector como forma de responder al shock del neoliberalismo.

\section{A modo de conclusión provisional}

En definitiva, el objetivo del presente trabajo ha estado orientado a contestar una serie de preguntas que se formulaban al comienzo del mismo: ¿Qué tipo de nuevas subjetividades han nacido en el estado de shock provocado por la dinámica neoliberal? ¿Qué nueva tendencia de conducta poética puede verse en los libros de los autores jóvenes españoles? ¿De qué manera ese choque del que son víctimas traspasa la escritura e interpela a los lectores?

El estado de shock provocado por el funcionamiento del sistema neoliberal ha dado lugar a nuevas subjetividades emergentes que, o bien asumen la lógica capitalista y la dinámica de la empresa donde el individuo termina extrapolando la competencia a todos los ámbitos de su vida cotidiana, o bien se rebelan frente a ese intento agresivo de privatización y se cuestionan la homogeneidad del sistema que invisibiliza los peligros. Todo ello traspasa hasta el terreno poético, y las obras de los autores jóvenes aquí 
estudiados actúan como un termómetro para medir la emergencia y el desarrollo de las nuevas subjetividades. Ahora bien, ese shock tiene diversos grados y formas de afectar a los poetas y estos, a su vez, también emplean diferentes recursos literarios para interpelar la sensibilidad de los lectores. La rabia, pero también la extrema dispersión de las voces poéticas, ha sido uno de los rasgos más comunes entre todos ellos. Esto traduce un momento socio-histórico en España en que el futuro de los individuos se ha vuelto confuso, provocando una búsqueda constante de identidad. En definitiva, lo que se pretendía en el presente trabajo era iniciar una línea de investigación que pudiera ser continuada en el futuro donde se mostrase cómo los poemarios de autores jóvenes reflejan el sentido bidireccional e histórico de sus obras en tanto receptores de un shock político concreto (crisis española) y en tanto productores de un shock estético a través de diferentes recursos literarios.

La poesía no puede derribar a una dictadura, pero sin poesía no hay absolutamente ninguna posibilidad de derribarla. Si los seres humanos no fuesen capaces de esa extrema delicadeza que es escribir poemas, la violencia sería lo natural, pero porque existen los poemas, la violencia, las matanzas, la tortura, los genocidios, son mucho más monstruosos. Porque si en lugar de torturar a alguien tenemos la posibilidad de tenderle una mano o de abrazarlo, el asesinato es infinitamente más asesinato y el asesino infinitamente más asesino (Raúl Zurita, 2014, entrevista en Eterna Cadencia). 


\section{Bibliografía citada}

Anónimo (2014). El bate de béisbol de Michael Douglas.

Azancot, Nuria. "Tenían 20 años y estaban locos. Luna Miguel publica una antología de poetas ultimísimos". El Cultural(2011).

Benjamin, Walter (1971). Sobre algunos temas en Baudelaire. Edición electrónica de Filosofía Universidad ARCIS.

Benjamin, Walter (1989). "La obra de arte en la época de su reproductibilidad técnica". Discursos Interrumpidos I. Buenos Aires: Taurus.

Bernstein, Charles, (ed.) (2006). La política de la forma poética. Poesía y política pública. La Habana: Torre de Letras.

Bourdieu, Pierre; Passeron, Jean Claude (2001). La reproducción. Madrid: Popular Colección.

Burger, Peter (1974). Teoría de la vanguardia. Barcelona: Ediciones Península.

Byung-Chul, Han (2012). La sociedad del cansancio. Barcelona: Herder: 56-57.

Calderón Gómez, Jorge. "Las vanguardias históricas en perspectiva". Nómadas. Revista crítica de ciencias sociales y jurídicas, Madrid (2005).

Casado, Miguel. "Hablar contra las palabras -Notas sobre poesía y política". Zurgai (2003): 38-50.

Colectivo Alicia Bajo Cero (1997). Poesía y Poder. Valencia: Ediciones Bajo Cero.

Cooper, David (1978). El lenguaje de la locura. Barcelona: Ariel.

Cumsille, Kamal. "Shock y estado de excepción: Arte y Política moderna, Baudelaire y Benjamin". Universidad de Chile (2007).

De Vicente Hernando, César. "Poesía política: la lógica de una estética radical". Zurgai (2003): 24-30.

Díaz Martínez, Jorge. “Tenían veinte años...". Culturamas (2011).

Fernández-Savater, Amador. "Notas para una política no estadocéntrica". eldiario.es (2014).

Foucault, Michel (2003). Vigilar y castigar. Nacimiento de la prisión. Buenos Aires: Siglo XXI editores Argentina S.A.

Foucault, Michel (2006). Historia de la sexualidad, I, La voluntad de saber. Madrid: Siglo XXI editores. 
García Montero, Luis. "La otra sentimentalidad". El País (1983) (reed. En Javier Egea, Álvaro Salvador y Luis García Montero (1983). "La otra sentimentalidad". Granada: Don Quijote: 9-15.)

Girona, Nuria. "Oliverio Girondo: cómo hacer cosas con palabras". ESTUDIOS. Revista de Investigaciones Literarias (1996): 223-236.

Girona, Nuria. "Preludio VI: Chantal Maillard: el malestar de cualquiera". XIII Jornada Conjunta de los Colegios Clínicos. Formaciones clínicas del campo lacaniano (2013).

Guerra, María Cecilia. "Los ojos del ejército. Sobre el origen del término vanguardia en la teoría del arte". Aisthesis 38 (2005): 240-250.

Iravedra, Araceli. "Radicales marginales y heterodoxos en la última poesía española (contra la "poesía de la experiencia')". Anales de la literatura española contemporánea (2003): 119-138.

Klein, Naomi (2007). La doctrina del shock: el auge del capitalismo del desastre. Barcelona: Paidós Ibérica.

Laval, Christian; Dardot, Pierre (2013). La nueva razón del mundo. Barcelona: Gedisa.

Martínez Rubio, José (2014). El futuro era esto. Crisis y rematerialización de la Modernidad. Dijon: Orbis Tertius: 47-50.

Méndez Rubio, Antonio. “Otra poesía es posible”. Zurgai(2003): 11-17.

Méndez Rubio, Antonio. "Des(a)punte sobre poética, política y figuración". Poesía sin mundo (2004), Mérida: Editora regional de Extremadura: 35-47.

Miguel, Luna (ed.) (2011). Tenían veinte años y estaban locos. Madrid: La Bella Varsovia.

Montero, Josu. "Breve génesis de la poesía política española actual: subversión lingüística y realismo crítico". Zurgai (2003): 6-10.

Mouffe, Chantal (1999). El retorno de lo político. Barcelona: Editorial Paidós.

Negri, Antonio; Hard, Michael (2002). Imperio. Barcelona: Editorial Paidós.

Oleza, Joan. "Luís García Montero: el desafío de una poesía sostenible". J.C. Abril y X. Candel (eds.) El romántico ilustrado, Sevilla: Renacimiento (2009): 169-183.

Oleza, Joan. "De la muerte del Autor al retorno del Demiurgo y otras perplejidades: Posiciones de autor en la sociedad globalizada", en Raquel Macciuci (ed.) Siglos XX y XXI. Memoria del I Congreso Internacional de Literatura y Cultura Españolas Contemporáneas (2008). Reeditado en Raquel Macciuci (ed.) (2010) La Plata lee a España. Literatura, cultura, memoria. La Plata: Ediciones del lado de acá: 15-48.

Peris Blanes, Jaume (2005). La imposible voz. Memoria y representación de los campos de concentración en Chile: la posición del testigo. Santiago de Chile: Cuarto Propio. 
Peris Blanes, Jaume (2008). Historia del testimonio chileno. De las estrategias de denuncia a las políticas de memoria. Valencia: Quaderns de Filologia.

Peris Llorca, Jesús. "Las poéticas del rock independiente español” (2014) (inédito).

Reyzábal, María Victoria. "Corrimiento poético: de la lucha social a la conciencia de otras marginalidades". Zurgai (2003): 31-37.

Riechmann, Jorge. "Empeños". Zurgai(2003): 18-23.

Scarano, Laura. "Intervenciones críticas en la poesía última (Prácticas de articulación y agendas complementarias)"“. Orbis Tertius: Revista de Teoría y Crítica Literaria.

Scarano, Laura (1994). La voz diseminada: hacia una teoría del sujeto en la poesía española. Buenos Aires: Biblos.

Vallejo, César. "Duelo entre dos literaturas". Universidad2 (1931): 13.

Zavala, Iris M. "La injuria, la palabra poética, la realidad: Lacan y vuelta a la metáfora". Escalera Cordero, Matías (ed.). La (re)conquista de la realidad. La novela, la poesía y el teatro del siglo presente. Madrid: Tierradenadie ediciones.

Žizek, Slavoj (2009). Sobre la violencia. Seis reflexiones marginales. Barcelona: Paidós Ibérica.

Žizek, Slavoj. "Beauvois y la libertad leninista". Tratado de la servidumbre liberal, de Jeanléon Beauvois (2008).

Zurita, Raúl (2014): entrevista en la página web de la librería y editorial Eterna Cadencia.

VV. AA., (2011). Calle de las impertinencias, Valencia: autoedición con el apoyo de la Universitat de València.

\section{Filmografía}

Schumacher, Joel (1993). Un día de furia. Warner Bros. 


\section{ANEXOS}

\section{Entrevistas}

Las dos preguntas han sido realizadas a todos los poetas cuyas respuestas aparecerán a continuación:

1. ¿Desde qué concepción de la poesía escribes? Es decir, cpodría decirse que tu poética nace desde el respeto a la tradición y en continuación de la misma o hay un ápice de "revolución lingüística y temática" entre tus versos? Como dicen muchos: ¡cabe todo en la poesía?

2. ¿En qué medida el contexto histórico que nos rodea influye en tu creación poética? Y si lo hace, ¿de qué manera?

\section{Emily Roberts (Laura de la Parra Fernández):}

1. Pienso que para querer aportar algo "nuevo" o cambiar algo es necesario conocer y respetar la tradición, pues en su día esta supuso la novedad y el cambio. También creo que nada se crea de la nada; la poesía nace como respuesta al mundo, pero también como respuesta a más poesía (si no, ¿ipor qué no decantarse por otra forma artística?). Considero que la poesía, y el arte en general, suponen un diálogo sobre temas muy antiguos y muy poco variados, a saber, el amor y la muerte, frente a los que se pueden aportar posturas y respuestas nuevas según el momento histórico y la subjetividad que habita cada autor. Se crean subtemas distintos (la libertad, la amistad, el hogar, etc), pero la pregunta, se responda como se responda, sigue estando ahí, y eso es lo que empuja al autor a escribir. Creo que lo que importa es el detalle, cómo se plantee una respuesta a esa pregunta (si llega a plantearse), y en la innovación de la forma puede llegar a caber todo en tanto en cuanto tenga una relevancia poética, es decir, comunique algo.

2. Como dice Marta Sanz en su ensayo No tan incendiario (Periférica, 2014), no todos los textos son políticos, pero sí ideológicos, es decir, están permeados por unos valores y una forma de ver el mundo que responde a la subjetividad del autor, y estas ideas dependen en gran medida del contexto histórico (incluso aunque las ideas sean contrarias a la política que un autor pueda defender en un texto político). Esto no quiere decir que todos los autores de una época vayan a tener las mismas preocupaciones o las mismas respuestas ante un tema; ni siquiera las mismas inquietudes. Si miramos por ejemplo antologías "generacionales", como Tenían veinte años y estaban locos (La Bella Varsovia, 2011) o Réquiem por Lolita (Fundación Málaga, 2014), por nombrar dos cuyos autores están próximos a mi edad, podemos encontrar muchas similitudes, pero también muchas diferencias. Esto es porque el lenguaje, por suerte, es orgánico y está inscrito en un momento temporal (e ideológico), pero también se ve afectado por muchas otras variantes más sutiles, como las vivencias personales, la educación, las lecturas, la sensibilidad del autor y el espacio. Yo no considero que mis textos sean políticos, pero el ambiente, y sobre todo, el espacio en el que se conciben, es una parte esencial de mi poética. 


\section{Ángel de la Torre:}

1. Creería imposible escribir de la nada. Es decir, la lectura, la tradición, es un camino que decididamente te influye a la hora de madurar una voz propia. Por otra parte, no creo que haya poesía sin revolución, sin cambio de dirección, sin más allá. Una revolución tanto lingüística como temática porque, al fin y al cabo, sería irreconciliable decir ahora con una lengua de ayer.

2. En cuanto al contexto histórico, cualquier poeta se siente marcado por el devenir histórico, pero la manera que tiene ese contexto de mostrarse en su producción poética puede ser más o menos explícito, más o menos soslayado. Esta última generación de poetas que está surgiendo y que tú estás estudiando está tomando en gran consideración el ambiente generado por los acontecimientos históricos y lo está introduciendo en su poesía de manera muy sutil e inteligente. Pienso en Elena Medel, pienso en David Leo García. En mi caso, la situación de desencanto que estamos viviendo me ha influido mucho en mi producción poética, que quizá se ha hecho más pesimista y oscura con el tiempo, no tanto en la temática sino en la voz, en la lengua. Además, mis circunstancias personales me han hecho acercarme a otras realidades históricas y otros movimientos sociales como los ocurridos en los países árabes, la llamada primavera árabe, que se ha manifestado de manera muy heterogénea y que también se encuentra en mi poesía ya sea directamente o como una manera diferente de interpretar la realidad que vivo y que percibo.

\section{Cristian Alcaraz:}

1. Mi poética nace como continuación, en cuanto a temática relacionada con lo masculino y lo homosexual, de la poesía de grandes poetas como Pablo García Baena, Juan Antonio González Iglesias o Antonio Portela. Cabe decir que la forma es la que cambia, por ejemplo en Turismo de interior (La Bella Varsovia, 2010), la poesía de Pablo García Casado queda como referente en cuanto a lenguaje y estilo lingüístico. Podría decirse, por lo tanto, que mi poesía es una continuación de otros autores pero desde un punto de vista renovador en cuanto a temática o referencias (Cruising, redes sociales, cibersexo, etc.). Sí, pienso que todo tiene cabida dentro de la poesía.

2. Ya sea contexto histórico o contexto social, cualquier enmarcación hace que la poesía se constituya de una forma y no de otra. Mi poesía, por ejemplo, tiene mucho de personal, pero también tiene mi juicio social en cuanto a la desesperanza ante una realidad de promesas y valores rotos. La Historia forma parte del poema, así como el poema narra partes de la Historia. Van unidos. No podría entender que mi poesía fuera sincera y hablara de mí, si ella misma se aleja de lo que vivo realmente y de lo que necesito describir.

\section{Fran Garcerá:}

1. No creo que en mi poesía se produzca una revolución lingüística o temática, puesto que en poesía como en casi cualquier otra materia, todo está hecho o dicho. En mi opinión, nada más debemos profundizar en la asombrosa fecundidad de nuestra poesía 
durante el último siglo, para ver que todas las preguntas están hechas y todas las formas exploradas. No obstante, siempre hay revolución en tanto en cuanto la mirada desde la que se inscribe cada individuo es original y única. Están hechas las preguntas, pero no tenemos las respuestas. El modo de ver las cosas, asimilarlas y escribirlas, es propio y revolucionario pues cada uno establece un diálogo distinto con todo aquello que le rodea y le complementa, encontrando formas distintas de desbordarse o contenerse.

Por lo tanto, en mi caso, no creo que rompa ni continúe con la tradición, solo me encuentro en la búsqueda por una palabra exacta que dé cuenta de mis heridas e inquietudes. No podría dar una respuesta más concreta y menos confusa que esta. Si no fuese así, estaría dando por sentado mi mundo poético y condenando toda la (r)evolución que debe producirse a lo largo de la trayectoria creativa de todo poeta que explora, que cambia, que se pregunta por tantos y tantas cosas, siempre en busca de una respuesta y una compresión que no terminan de darse. Elena Poniatowska, en su reciente discurso con el que recibió el premio Cervantes, dijo: "Tampoco la naturaleza dice lo que es ni se explica a sí misma, simplemente estalla". Aplicada a mi quehacer poético, creo que esa sería una buena respuesta para salir airoso de esta pregunta. De igual modo, dicha afirmación también daría cuenta de la diáspora estética (Á. L. Prieto de Paula) a la que asistimos en el panorama poético actual, afortunadamente, lejos de la supuesta facilidad generacional con la que antes se agrupaba y se excluía a los poetas. Ahora, como siempre, todo cabe en la poesía. Ahora, pero no como ha sido siempre, todo puede llegar a la poesía publicada con una mayor facilidad.

2. Según el poeta Antonio Cabrera, al que admiro y respeto, el individuo se conforma del diálogo que se establece en su conciencia entre el mundo externo y el interno. De esta interacción, afirmó: Los poemas, pues, sirven para subrayar lo vivido. A mi entender, partiendo de este punto, un poeta puede tomar distintas determinaciones: luchar contra el contexto histórico que le oprime, ignorarlo y huir de este o las dos cosas, quiero decir, lanzar el grito necesario pero también recogerse en su estancia íntima. Yo me inscribiría en este doble movimiento, puesto que el contexto histórico, la época de indignidad a la que estamos asistiendo, influye notablemente en mi mirada, en mi mundo externo. Pero también es necesario cierto recogimiento, esto es, mi mundo interno. Y en ese choque que se da entre los dos es donde se produce mi sobresalto, donde se mueve mi necesidad y mi pregunta. Como todo cabe en poesía, sería empequeñecer la mirada quedarse en una sola posición.

Así, y acogiéndome a otra poeta, la excelentísima Ángela Figuera Aymerich, una de nuestras mejores poetas del siglo XX y también una de las más infravaloradas, debo decir que no espero que mi poesía cambie el mundo. Ni la mía ni la de ningún otro. Quizá solo debemos esperar, como dijo ella, acompañar y aliviar con nuestra poesía la soledad que acoge y abate al ser humano en este contexto que vivimos: ACOMPAÑAR al hombre: al desposeído, al maltratado, al despreciado. Pero si otra cosa debe hacer la poesía, o el poeta, es erigirse como testimonio de la memoria. Decirlo todo. Nombrarlo todo. Preguntarse todo. Hay una percepción distinta en la poesía, más inmediata y primigenia, que no alcanza a la novela o a los otros géneros (lo mismo ocurre al contrario en otros aspectos), que debe ser aprovechada para dar buena cuenta a las próximas generaciones de lo convulso, atroz y 
falso que tienen nuestros días, para contraponer una historia distinta, más humana y cierta, a la que se establece como la historia oficial de nuestros siglos.

Para recapitular, creo que en esta doble vertiente, en este punto medio donde me ubico con mi poesía, influye indiscutiblemente el contexto histórico. Me erïo en la obligación de dar cuenta del miedo y de acompañar al ser humano en su camino. Pero no puedo eludir (no habría forma posible de lograrlo) preguntarme sobre la luz, sobre el aire, sobre la sombra o dar cuenta de mi estancia interior y mínima donde coger aliento. Al fin y al cabo, recorro el mismo camino de una juventud que se exilia, que se pierde, que se sienta traicionada, que aprende a besar en otros idiomas y también, digámoslo, que es obligada a llorar en los aeropuertos, a llorar en lenguas dispares y en silencio, que cuida de niños lejos de casa y de sus maletas. Hay que decirlo, definitivamente, todo.

\section{Carlos Loreiro:}

1. En realidad no creo que haya leído, reflexionado y escrito lo suficiente como haberme hecho una idea de mi propia concepción sobre la poesía. Sí puedo decir que en ella no hay nada de revolución, ni lingǘstica, ni temática ni estructural: he usado lo que ya estaba inventado. Si esas formas y temáticas están ahí es porque son efectivas. No veo por qué no usarlas, así uno puede centrarse en lo que creo que es en realidad importante en estos casos, que es contar algo que resulte (o al menos parezca) interesante, tanto para uno mismo como para otros. Podría decirse que respeto la tradición y trabajo sobre ella, eso si entendemos "tradición" solamente como aquello de lo que disponemos para tomar referencias. Entiendo además las referencias como una especie de expropiación que difiere tal vez del plagio en la medida en que uno sea capaz de transformar lo que ha tomado. Creo que un escritor llega a ser bueno cuando consigue disfrazar y dotar de coherencia todo aquello que ha plagiado de un lado y de otro. En mi caso tal vez las influencias que haya podido tener (derivadas de esas referencias o plagios) no vienen tanto de la poesía española como de ciertas literaturas muy puntuales que tomo de aquí y de allá, y esto en realidad es tan solo una cuestión de afinidad, lo cual es una pena, porque sería más interesante poder decir que es una estrategia más en el proceso de ocultación de lo que he robado: es más fácil robarle al vecino, pero también hay más posibilidades de que te pillen. De todos modos, como ya he dicho, me baso absolutamente en la tradición. Hacer esto es mucho más sencillo a la hora de escribir poesía, sobre todo si pensamos en la recompensa que generan esfuerzos de este tipo, que es ninguna. Por otra parte, en lo que respecta a si cabe todo en poesía, puede que por caber, quepa todo. Otra cosa es estar dispuesto a jugársela de esa manera: supongo que todo depende de cuántos lectores aspire uno a tener.

2. Las circunstancias por las que corre la suerte de uno mismo me parecen el motivo fundamental por el que escribir, y no solo sobre el que escribir. Es decir, si acaso el contexto histórico me quedaría muy grande (actualmente y por motivos extrapersonales, ni estudio ni trabajo, así que no se me podría considerar un ente social o político, o como quiera llamarse) son exclusivamente las vicisitudes personales las que me mueven a escribir. Para tomar una base sencilla y útil sobre la que desarrollar un poema suelo partir de la conceptualización de aquel sentimiento que sea capaz de resumir, por ejemplo, un día 
normal en mi vida. Cuando lo tengo, trabajo sobre él. Si tomamos, por ejemplo, el sufrimiento como concepto extraído del balance de una jornada cualquiera, la historia que cuente ese poema tendrá por eje vertebrador la idea de sufrimiento, que se vuelve casi un tema. El problema es que ese concepto tiende a repetirse a lo largo de los días. Es por eso que, aunque intente contar historias diversas, da siempre la sensación de que me repito. No sé si es por tanto una buena estrategia; en todo caso es la única de que dispongo. Mi única baza es carecer de convicciones, y creo humildemente que si hay algo interesante en los textos que escribo, ello viene directamente de la ausencia de ideas propias.

\section{Merche Ribas:}

1. Bueno, "respeto a la tradición" es un concepto que no usaría aunque me gusten poetas que estén dentro del canon en muchas épocas (ni todos ni en todas). Sí que recuerdo un momento digamos fundacional en mi forma de escribir y es que estaba dentro de una clase de poesía y me parecía todo tan soberanamente elitista y postizo que ahí mismo surgió un poema muy visceral contra lo que desde una ideología rancia se considera "la tradición" y sobretodo el modo arcaico de transmitirla. No sé si cabe todo en la poesía. Es una pregunta tramposa El arte institucionalizado contempla un tipo de poesía en el que cabe muy poco. Mi interés está más enfocado en los disparadores de una cotidianidad creativa, pintadas en las calles, letras de canciones, frases de todos los días con las que es divertido jugar. La simple intención de manipular el lenguaje por su forma me atrae, sobre todo si mueve también los referentes, no como puro juego de formas. Sé que algunas personas desde dentro de la institución contemplan todo esto. Y algunos sectores están renegociando las viejas estructuras de transmisión del conocimiento. Ahí cabe mucho.

2. El contexto histórico atraviesa mi persona, mi lenguaje. A nivel temático, por ejemplo, creo que no podría tratar la sexualidad como lo hago si no hubiera habido una batalla campal para frenar el patriarcado durante tantos años por parte de la resistencia feminista. A mí se me habría educado de otra forma, y aunque hayamos ganado mucho terreno en cuestiones de igualdad, los roles de género me los pincharon en vena. Por lo menos va existiendo todo un dispositivo de alarmas que te va haciendo ver las grietas del sistema y te permite reconstruirte. Por otro lado, estamos en el gran momento de destapar la gran estafa que es la estructura política del estado, de linaje claramente franquista. La denuncia forma parte del idioma, cómo nombramos la realidad, qué significa "democracia". Si hablamos de otra manera, ya estamos viviendo de otra manera (acción), sin esperar a que tenga que derrumbarse todo desde arriba.

\section{Anónimo (autor de $E l$ bate de béisbol de Michael Douglas):}

1. Más que respeto a la tradición creo que tiene que haber una lectura de la tradición, que es didáctica condición de posibilidad de la creación artística original. Para que tenga lugar este diálogo es necesario que la lectura de lo anterior, de lo institucionalizado, produzca moderna insatisfacción y desamparo. No estoy seguro de que en este poema haya una revolución tanto lingüística como estructural, conceptual o relativa a los códigos de la poesía social. Creo que la presentación del texto (entradas de Tumblr) y 
su distribución (libre) son más revolucionarias en este sentido. La poesía, creo, es un dispositivo lingǘstico moderadamente fallido que inaugura tipos de comunicación. En este sentido no es fácil anticipar qué cabe o qué no cabe en ella.

2. Es una circunstancia fundamental que exista la posibilidad de acceso gratuito a la cultura; es decir, la libre distribución de libros, películas y discos. Hoy cualquier autor se plantea la elección entre el estertor de la edición y distribución clásicas o bien las nuevas posibilidades tecnológicas. Para quien escribe una literatura con dimensiones políticas, con cierta vocación de incidir en el mundo, la elección es sencilla. La posibilidad de editar textos sin la mediación de editoriales también obliga a escoger entre dos opciones: la tapa dura, institución legitimadora, o la impertinencia virtual, esa jungla aparentemente caótica. 